\title{
Geochemical study of arsenic release mechanisms in the Bengal Basin groundwater
}

\author{
Carolyn B. Dowling, ${ }^{1}$ Robert J. Poreda, Asish R. Basu, and Scott L. Peters \\ Department of Earth and Environmental Sciences, University of Rochester, Rochester, New York, USA
}

\author{
Pradeep K. Aggarwal \\ International Atomic Energy Agency, Vienna, Austria
}

Received 26 September 2001; revised 28 February 2002; accepted 18 March 2002; published XX Month 2002.

[1] To investigate arsenic mobility in the Bengal Basin groundwater, we sampled water wells and sediments throughout the region. There are strong correlations among high levels of dissolved arsenic and iron, ammonia, and methane, especially in samples from a single site (Laxmipur). No linkage is seen between As and agricultural tracers such as phosphate. The association of As and Fe occurs because arsenic strongly adsorbs onto $\mathrm{FeOOH}$ particles in river water. They flocculate with other fine-grained particles at the freshwater/saltwater transition zone. Subsequent bacterially mediated reduction of $\mathrm{FeOOH}$ in the clay releases the adsorbed arsenic. Weathering of As-bearing mica plays a significant role in the As budget. The "correlated" presence of $\mathrm{As}, \mathrm{CH}_{4}$, and $\mathrm{NH}_{4}$ in water supply wells is the result of diffusion out of organic-rich clay into the more permeable zones. Arsenic is mainly released from recent sediments at $<50 \mathrm{~m}$ depth deposited in the GBR floodplain as sea level rose throughout the Holocene. INDEX TERMS: 1065 Geochemistry: Trace elements (3670); 1829 Hydrology: Groundwater hydrology; 1831 Hydrology: Groundwater quality; KEYWORDS: arsenic, groundwater, Bengal Basin, hydrogeochemistry, iron oxyhydroxides, microbes

\section{Introduction}

[2] Since the 1970s, the World Health Organization has drilled more than two million tube wells in Bangladesh for the population to have a safe, bacteria-free drinking water supply. Unfortunately, under certain conditions, the groundwater frequently contains elevated levels of natural arsenic, greater than the World Health Organization's maximum contaminant level (MCL) of $0.01 \mathrm{ppm}(0.13 \mu \mathrm{M})$ and often times greater than the Bangladesh's MCL of $0.05 \mathrm{ppm}(0.66$ $\mu \mathrm{M})$. Arsenic, a notorious bio-accumulating poison, has been adversely affecting the health of millions of people in the Bengal Basin (Bangladesh and the West Bengal State, India) for the last twenty years [Das et al., 1995, 1996; Mandal et al., 1996; Dhar et al. 1997; Biswas et al., 1998; Karim, 2000; Smith et al., 2000].

[3] The Bengal Basin lies within in the floodplain of the Ganges and Brahmaputra Rivers (GBR). As one of the world's largest river systems, the GBR transports the single largest sediment flux and the fourth highest water discharge to the oceans [Holeman, 1968; Coleman, 1969; Milliman and Meade, 1983]. Based on the average As of $0.07 \mu \mathrm{mol} / \mathrm{L}$, the GBR delivers an estimated $7.0 \times 10^{7} \mathrm{~mol} / \mathrm{yr}$ of dissolved As to the Bay of Bengal annually. The majority of this arsenic is most likely removed during the flocculation of fine-grained particles at the saltwater/freshwater interface in the estuaries of the Bengal Basin or, under certain extreme

\footnotetext{
${ }^{1}$ Now at Byrd Polar Research Center, Ohio State University, Columbus, Ohio, USA.

Copyright 2002 by the American Geophysical Union. 0043-1397/02/2001WR000968\$09.00
}

reducing conditions, bacterially reduced and precipitated as diagenetic pyrite in the swampy, anoxic wetlands of the GBR delta. From the combined effects of sea level change, migration of river channels and variable patterns of sedimentation, the boundary between fresh and seawater has varied greatly over the past million years. These sedimentary processes have led to a complicated subsurface distribution of arsenic, which is presently being liberated into the groundwater of the Bengal Basin.

[4] There have been several recent studies of the Bengal Basin groundwater in an attempt to understand the mechanisms that mobilize arsenic into the groundwater. Several existing and competing theories have been suggested to explain the arsenic release into groundwater, such as the oxidation of pyrite [Mallick and Rajagopal, 1996; Mandal et al., 1998; Chowdhury et al., 1999], competitive exchange with fertilizer phosphate [Acharyya et al., 1999, 2000], and dissolution of iron oxy-hydroxides [Nickson et al., 1998, 2000; McArthur et al., 2001]. The pyrite oxidation process would require either dissolved $\mathrm{O}_{2}$ or $\mathrm{NO}_{3}$ as an electron acceptor, acidified water, and measurable quantities of sulfate. In general, none of these conditions are met for a significant number of groundwater samples [Nickson et al., 2000; McArthur et al., 2001; this study]. Phosphate, an important component of fertilizer, may replace sorbed arsenic on the sediment surfaces through competitive exchange thereby releasing As to the groundwater. We would expect to find higher As in shallow wells near recently cultivated fields.

[5] Some studies have focused on the arsenic cycle with an emphasis on adsorption and desorption reactions on iron oxides. The results of these studies show that iron oxy- 
hydroxides $(\mathrm{FeOOH})$ strongly adsorb arsenic, as $\mathrm{As}_{2} \mathrm{O}_{4}^{2-}$ or $\mathrm{AsO}_{4}^{3-}$, in the river water [Moi and Wai, 1994], and the Asladen $\mathrm{FeOOH}$ fine-grained sediments are deposited in the organic-rich estuaries and wetlands of the Bengal Basin. Many researchers have identified a correlation between $\mathrm{Fe}$ and As in the groundwater and hypothesized that the dissolution of iron oxy-hydroxides releases As into the groundwater [Nickson et al., 1998; Cummings et al., 1999; Nickson et al., 2000; McArthur et al., 2001]. Cummings et al. [1999] and McArthur et al. [2001] believe that, in the moderately reducing groundwater of Bangladesh, the microbial mediated reductive dissolution of $\mathrm{FeOOH}$ is liberating arsenic from the sediment into the water. The redox boundary for the ferric/ferrous transition is close to the arsenate/ arsenite boundary for neutral $\mathrm{pH}$ and suggests that a significant amount of arsenic in groundwater may occur as arsenite $[\mathrm{As}(\mathrm{III})]$ which is more mobile at lower $\mathrm{pH}$ values and more toxic than arsenate $[\mathrm{As}(\mathrm{V})]$.

[6] The purpose of this study is to describe the groundwater geochemistry and determine the mechanisms of arsenic release from the sediment into the Bengal Basin groundwater. An important component of our research is to evaluate the groundwater residence time for both the As and non-As bearing wells since earlier studies have suggested a depth control to the As distribution and possible link between recent agricultural activities (phosphatic fertilizer and excessive extraction of groundwater for irrigation) and elevated arsenic [Acharyya et al., 1999, 2000]. We collected sixty-eight groundwater samples, specifically for determining major and trace elements, dissolved gas, helium isotopes, and tritium, according to standard methods. The samples were taken from a variety of localities and measured for major and trace elements to establish the regional geochemistry of the groundwater and the extent of the As problem. Across the Bengal Basin, we sampled wells at multiple depths $(9-335 \mathrm{~m})$ to establish the vertical groundwater velocity and, hence, the recharge rate to the aquifer by using tritium, ${ }^{3} \mathrm{He}$, and ${ }^{4} \mathrm{He}$ concentrations. Additionally, sediment extraction and digestion experiments were performed on a sediment drill core from Laxmipur, Bangladesh (a location with high dissolved As in groundwater) to determine the role of adsorption/desorption reactions on sedimentary grain surfaces in controlling the trace metal concentrations in the groundwater and to establish the source of arsenic being released to the groundwater.

\section{Geology of the Bengal Basin}

[7] The drainage area of the Ganges-Brahmaputra Rivers is approximately $2 \times 10^{6} \mathrm{~km}^{2}$ [Holeman, 1968; Coleman, 1969], and its average annual water discharge is $1.0 \pm 10 \times$ $10^{12} \mathrm{~m}^{3} / \mathrm{yr}$ [Subramanian, 1979]. Despite the high sediment load to the Bay of Bengal $\left(1.5 \times 10^{12} \mathrm{~kg} / \mathrm{yr}\right)$, the shoreline of the GBR delta is relatively stable. The delta is only growing at $7 \mathrm{~km}^{2} / \mathrm{yr}$ while parts of the sediment-starved western delta are retreating at $1.9 \mathrm{~km}^{2} / \mathrm{yr}$ [Allison, 1998]. Most of the sediment in the GBR is channeled into deeper water by canyons to create one of the largest global submarine deltas, the Bengal fan. The heavy sediment load, strong oceanic currents, tectonic subsidence, major seismic events, and the Swatch of No Ground canyon system heavily influence the sedimentation rates of the subaerial delta, shelf, and submarine delta. Conditions over the last 20,000 years have varied greatly as sea level rose $120 \mathrm{~m}$. The large GBR sediment discharge during this time was sufficient to accommodate aggradation and subsidence and maintain shoreline stability. Based on radiocarbon ages, the overall accumulation rate for the Bengal Basin over the last 10,000 years ranges between $3.2 \pm 0.8 \mathrm{~mm} / \mathrm{yr}$ and $5.0 \pm 1$ mm/yr [Umitsu, 1993; Goodbred and Kuehl, 2000]. According to field measurements on the Brahmaputra River, the present sedimentation rate varies from 7.5 to $11.5 \mathrm{~mm} / \mathrm{yr}$ leading to a $15 \mathrm{~m} / \mathrm{yr}$ seaward advance of the Bengal Fan [Michels et al., 1998].

[8] Within the Ganges-Brahmaputra floodplain, the Bengal Basin consists of mostly quaternary deltaic sediments of the Ganges and Brahmaputra rivers and the alluvial deposits from the weathering of the Himalayas. The Bengal Basin is $\sim 1.4 \times 10^{5} \mathrm{~km}^{2}$ in area and covers most of Bangladesh and part of the West Bengal State in India (Figure 1). The subsurface geology of the Bengal Basin has complex interfingerings of coarse and fine-grained sediments from numerous regressions and transgressions throughout geologic time. Umitsu [1993] and Goodbred and Kuehl [2000] classified the Late Quaternary sediments of the coastal region. The Oxidized Facies (lowermost unit) are weathered paleosols of the Late Pleistocene lowstand. The Sand Facies (lower unit) is made of medium-fine sand, represents channel fill and early transgressive alluvial valleys, and is older than 12,000 years. Above the Oxidized and Sand Facies, a sharp transition occurs to the fine-grained organicrich Lower Delta Mud (middle unit) whose thickness varies between 5 and $30 \mathrm{~m}$. The Lower Delta Mud, consisting of clay and sandy clay layers, results from a change in the depositional environment during the early Holocene caused by the rapid rise in sea level and flooding on the lower delta. The Lower Delta Muds range from 7857 and 9917 radiocarbon years while the ages of the overlying sequence, Muddy Sand (upper unit), vary between 4770 and 7382 years. The Muddy Sand unit (5-35 m thick) is divided into clay (lower), peat (middle), and peaty silt (upper) layer and suggests a gradual environment transition from decelerating sea-level rise with lower flow conditions, increased channel mobility, and widespread distribution of fluvial sands across the coastal plain.

[9] From $\sim 5000$ to $\sim 7000$ years ago, the Ganges River sediment was still being transported to the western margin of the basin. However, during this time, the Brahmaputra river sediment was being trapped in the Sylhet Basin causing sediment starvation and transgression along the eastern coast. Around $\sim 5000$ years ago, the Ganges river began migrating easterly towards the Brahmaputra river. The shoreline in the eastern delta has been prograding into the Bay of Bengal for the past several thousand years. The remaining unit, Thin Mud (uppermost; 5-20 m thick), has a bottom layer of peaty clay and a top layer of silt that characterizes the formation of marshy lands and floodplain deposits for the last $\sim 5000$ years.

[10] The Bengal Basin soils are a mixture of clays, quartz, calcium carbonate, dolomite, and mica [Food and Agricultural Organization (FAO), 1971]. In general, the subsurface mineralogy of the Bengal Basin is dominated by quartz with some plagioclase and potassium feldspar and volcanic, metamorphic, and sedimentary fragments [Uddin and Lund- 


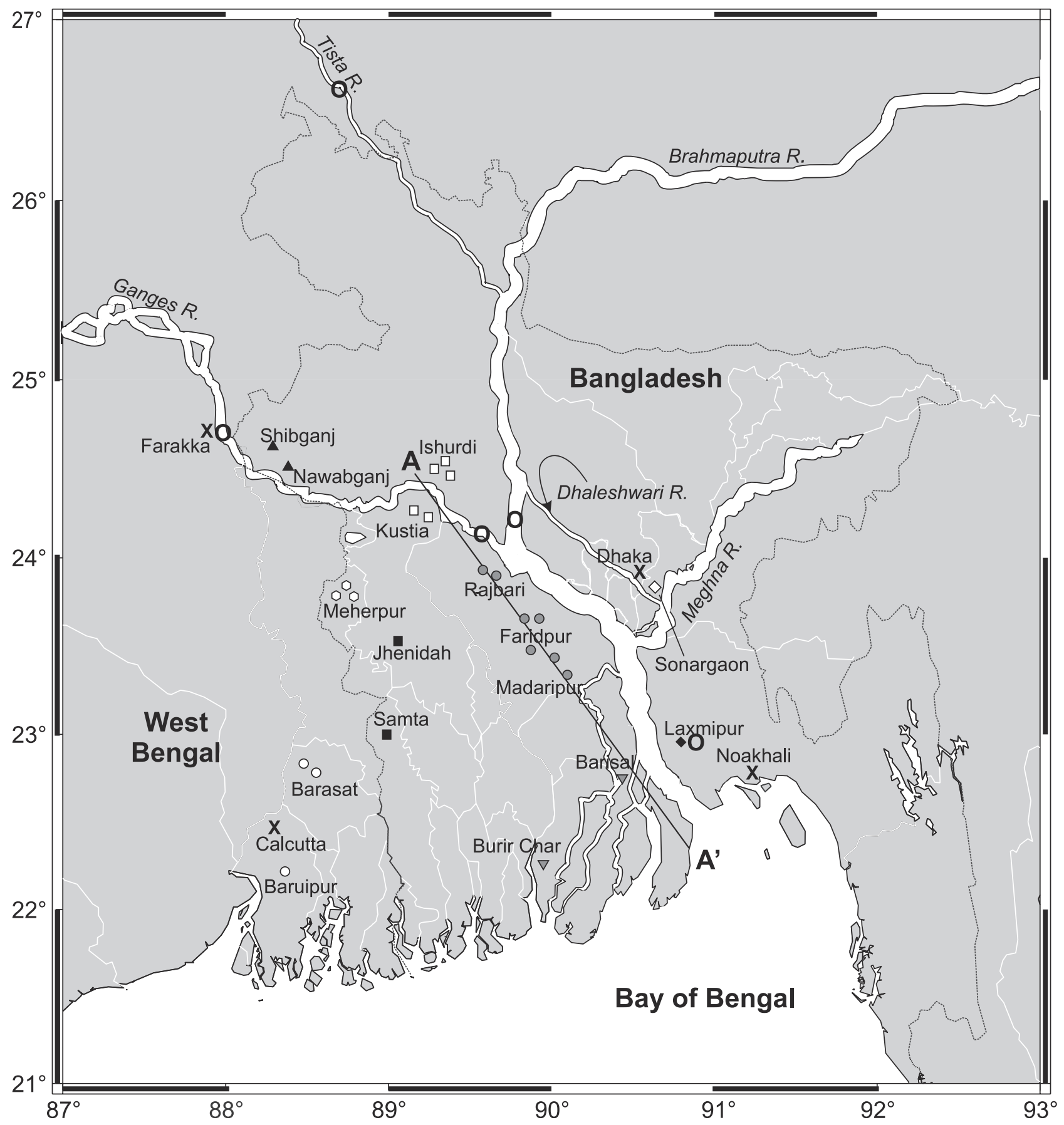

Figure 1. Bengal Basin groundwater and river sediment collection sites. This map shows the location of groundwater (variety of symbols) and river sediment (thick open cirlces) samples in Bangladesh. The sediment samples (thick open cirlces) are from Laxmipur and the northern and southern Ganges and Brahmaputra Rivers (collected by W. S. Moore and A. R. Basu). The crosses designate the larger towns.

berg, 1998]. Foster et al. [2000] divided the top $50 \mathrm{~m}$ in Ramrail, Brahmanbaria (near Dhaka) into two provisional sections where the upper section (6-25 m depth) is composed of gray to black micaceous fine-grained sand and the lower section (26-48 $\mathrm{m}$ depth) consists of medium to coarse-grained $\mathrm{FeOOH}$ coated quartz and weathered mica. Our Laxmipur drill core and river sediment samples are dominated by iron-stained quartz with some plagioclase and micas and a minor amount of carbonates as confirmed by our XRD and XRF analyses and optical microscopy. We esti- mate that larger $(150-250 \mu \mathrm{m})$ biotite and muscovite flakes compose $10-15 \%$ of Lax-3 (3 m depth), Lax-13 (13 m depth), and Lax-48 (48 $\mathrm{m}$ depth) and $3-5 \%$ of the bulk samples from Lax-23 (23 m depth) and Lax-39 (39 m depth). Our sediment grain-size analysis loosely corresponds to the units described by Umitsu [1993] and Goodbred and Kuehl [2000] and demonstrates the influence of localized transgressions and regressions on the stratigraphy. Silt (31-32\%) and very fine-grained sands $(31-36 \%)$ dominate the Lax-3, Lax-13, and Lax-48 samples at Laxmipur. Whereas the 
sediment at $23 \mathrm{~m}$ (Lax-23) consists of almost equal amounts of fine-grained sand (28\%), very fine sand $(26 \%)$ and silt $(26 \%)$, and Lax-39 is composed of fine-grained sand $(59 \%)$ and medium-fine sand $(20 \%)$.

\section{Sampling and Methodology}

[11] Sixty-eight groundwater samples were collected from monitoring and domestic wells in the Bengal Basin throughout Bangladesh and parts of West Bengal, India in May 1999 and January 2000 (Figure 1), according to standard methods [Long and Martin, 1991; Greenberg et al., 1992]. The sediment drill core was taken adjacent to the groundwater well cluster at Laxmipur (Figure 1). W. S. Moore (University of South Carolina) provided the river sediment samples upstream from the confluence of the Ganges (RW-54) and Brahmaputra (RW-53) Rivers [Sarin et al., 1989]. Asish R. Basu collected the northern Ganges and Brahmaputra river sediment samples at Rishikesh, India (Ganges) and Guwahati, India (Brahmaptura). Please refer to Figure 1 for the river sediment locations.

[12] We recorded field parameters $(\mathrm{pH}$, temperature, conductivity, bicarbonate, and latitude and longitude) at each well site. The samples for major element (cations and anions) and trace metal analyses were collected through $0.25 \mu \mathrm{m}$ polycarbonate filters. For the trace metal and cation samples, the filtered water was acidified to $\sim \mathrm{pH} 2$ with ultrapure nitric acid. We collected the samples for dissolved gas content and helium isotope analysis using 3/8-inch (I.D.) copper tubes and sealed with refrigeration clamps according to our established methods [Poreda et al., 1988]. Water samples for tritium analysis were stored in amber glass bottles with polyethylene caps to minimize watervapor exchange.

[13] We measured major cations and anions in the groundwater samples on a Dionex ion chromatograph (IC), using CS12A and AS4A Ion Pac columns, according to our established procedures at the University of Rochester [Fehn et al., 2000]. The analytical errors for these IC analyses were usually less than $6 \%$ for the cations and anions. Gas concentrations and isotopic ratio measurements of the groundwater samples were carried out at the Rare Gas Facility at the University of Rochester. The dissolved gas was extracted and processed on a high vacuum line [Poreda et al., 1988]. We measured the helium isotope ratio measurements with a VG 5400 noble gas mass spectrometer by peak height comparison to a calibrated air standard with errors of $\sim 2 \%$ [Poreda and Farley, 1992]. The tritium values were determined using the ${ }^{3} \mathrm{He}$ "in-growth" technique [Clarke et al., 1976]. The errors depend on the amount of ${ }^{3} \mathrm{H}$ and are \pm 0.1 T. U. (Tritium Units) or $\pm 5 \%$ at 5 T. U., whichever is greater.

[14] We sent the Laxmipur core samples to ALS Chemex, Mississauga, Ontario, Canada for XRF (X-ray Fluorescence) and organic carbon analyses. The mineralogical classification of the core was determined through X-ray diffraction (XRD) analysis using a Scintag XDS 2000. The bulk drill core was sieved for grain-sized analysis. We separated the clay-sized particles from the bulk sediment using floatation and the micas by hand using a Nikon SMZ$\mathrm{U}$ microscope.

[15] For the bulk and fine-grained sediments and mica separates, we used an ammonium oxalate acid reagent to extract the exchangeable and adsorbed trace metals [McKeague, 1978]. Ten $\mathrm{mL}$ of $0.2 \mathrm{M}$ oxalate solution was added to $0.25 \mathrm{~g}$ of sediment (or any proportion thereof) and agitated horizontally for four hours in the dark. We then rinsed the bulk samples with $18 \mathrm{M} \Omega$ water, added $30 \%$ ultrapure $\mathrm{H}_{2} \mathrm{O}_{2}$ and $0.02 \mathrm{M}$ ultrapure $\mathrm{HNO}_{3}$, and heated them $\left(85^{\circ} \mathrm{C}\right)$ for five hours to breakdown the organic fraction (modified from $\mathrm{Li}$ et al. [1995]). Following the oxalate extraction procedure, the clay-sized particles and micas were then rinsed with $18 \mathrm{M} \Omega$ water, dried, and then digested using a Milestone MLS 1200 microwave digestion system. The digested samples were evaporated to dryness and re-acidified them using ultrapure nitric acid.

[16] Iron concentrations for groundwater and sediment extracts were determined using a Shimandzu UV-Visible (UV-Vis) Spectrophotometer. We prepared the samples by adding hydroxylamine hydrochloride $(10 \% \mathrm{w} / \mathrm{v})$, FerroZine iron reagent, and ammonium acetate buffer solution (ammonium hydroxide and ultrapure glacial acetic acid) to them [To et al., 1999]. Errors in the UV-Vis calibration curves were generally less than $3 \%$. To prepare the groundwater, sediment extracts, organic fraction, and sediment digestions for trace metal analysis on the ICP-MS, we diluted the samples with $18 \mathrm{M} \Omega$ water and acidified them with ultrapure nitric acid. The analyses were done, according to US EPA Method 200.8 [Long and Martin, 1991], using the VG ICP-MS Plasma Quad II+ at the University of Rochester. To correct for drift, gallium, indium, and bismuth were added as internal standards for the water and sediment extraction samples. For the sediment digestions, we only used indium and bismuth. A five-point calibration curve was created using standards that are traceable to NIST. The standards were analyzed before and after a set of samples. We analyzed two NIST water standards (NIST 1640 and NIST 1643d) as unknowns. Based on these results, the errors in the trace metal concentration analyses were less than $5 \%$ for the samples measured on the VG ICP-MS Plasma Quad II+.

\section{Results}

\subsection{Groundwater Chemistry}

[17] The calcium carbonate rich groundwater in the Bengal Basin contain some sodium chloride, no sulfate, and background levels of most trace metals, except for $\mathrm{Sr}$, $\mathrm{Ba}, \mathrm{Fe}, \mathrm{Mn}$, and As (C. Dowling et al., The groundwaters of the Bengal Basin: Their geochemistry and trace metal flux to the oceans, submitted to Geochimica Cosmochimica Acta, 2002). Our results, listed in Table 1 and displayed in Figure 2, show that the elevated arsenic levels are concentrated in the shallow groundwater wells $(<60 \mathrm{~m})$. Forty-seven out of 68 samples or $69 \%$ of the wells are above the WHO standard $(0.01 \mathrm{ppm} ; 0.13 \mu \mathrm{M})$. This plot (Figure 2) of the As distribution with depth confirms the findings of the British Geological Society and others that show high As concentrations at shallow depths [Acharyya et al., 1999; British Geological Survey and Mott MacDonald Ltd., 1999; Chowdhury et al., 1999; Nickson et al., 2000; McArthur et al., 2001]. Some of the deeper wells (e.g., BGD $8,13)$ with high arsenic levels are multiple depth completion wells and are most likely tapping both shallow As-rich water and deeper As-free groundwater. Figure 2 also demonstrates that higher levels of $\mathrm{NH}_{4}, \mathrm{Fe}$ and $\mathrm{Mo}$ (as molybdate which is a redox sensitive oxy-anion, like arsenate) are 
Table 1. Bengal Basin Groundwater Sample Locations, Well Depths, Selected Major Ions, Gas, and Trace Metal Data ${ }^{\mathrm{a}}$

\begin{tabular}{|c|c|c|c|c|c|c|c|c|c|c|}
\hline $\begin{array}{l}\text { Sample } \\
\text { Name }\end{array}$ & Sample Date & Sample Location & Depth, m & $\mathrm{NH}_{4}$ & $\mathrm{CH}_{4}$ & $\mathrm{Mn}$ & $\mathrm{Fe}$ & As & Mo & $\mathrm{Ba}$ \\
\hline BGD 1 & May 1999 & Laximpur & 244 & 104.44 & $*$ & 3.23 & 37.17 & 0.02 & bdl & 1.76 \\
\hline BGD 2 & May 1999 & Sonapur & 11 & 222.22 & * & 8.90 & 14.38 & 1.57 & 0.05 & 0.08 \\
\hline BGD 3 & May 1999 & Faridpur & 20 & 273.33 & 1052.23 & 22.32 & 35.97 & 4.28 & 0.03 & 1.50 \\
\hline BGD 4 & May 1999 & Faridpur & 30 & 313.33 & 917.76 & 8.32 & 33.53 & 3.76 & 0.03 & 1.05 \\
\hline BGD 5 & May 1999 & Faridpur & 40 & 331.11 & 531.43 & 8.89 & 30.79 & 2.94 & 0.03 & 0.91 \\
\hline BGD 6 & May 1999 & Faridpur & 150 & nd & 14.63 & 15.17 & 10.90 & 0.04 & 0.01 & 0.80 \\
\hline BGD 7 & May 1999 & Faridpur & 50 & 346.67 & 301.66 & 4.62 & 38.28 & 2.57 & 0.02 & 1.19 \\
\hline BGD 8 & May 1999 & Faridpur & 244 & 286.67 & 1265.87 & 4.26 & 64.60 & 2.53 & 0.02 & 2.09 \\
\hline BGD 9 & May 1999 & Faridpur & 98 & 0.00 & 8.84 & 6.43 & 12.68 & 0.04 & 0.00 & 0.99 \\
\hline BGD 10 & May 1999 & Ahladipur & 30 & 17.78 & 8.01 & 17.71 & 16.07 & 0.49 & 0.01 & 1.29 \\
\hline BGD 11 & May 1999 & Rajbari & 48 & nd & * & 9.01 & 3.94 & 0.06 & 0.00 & 0.77 \\
\hline BGD 12 & May 1999 & Rajbari & 33 & nd & * & 19.02 & 8.32 & 0.39 & 0.01 & 0.57 \\
\hline BGD 13 & May 1999 & Rajbari & 127 & 46.67 & 8.68 & 13.37 & 46.91 & 0.72 & 0.01 & 1.10 \\
\hline BGD 14 & May 1999 & Talma & 44 & 385.56 & 734.04 & 2.55 & 107.82 & 0.79 & 0.01 & 1.28 \\
\hline BGD 15 & May 1999 & Nagarkanda & 29 & 224.44 & 268.32 & 8.26 & 121.48 & 2.92 & 0.02 & 1.84 \\
\hline BGD 16 & May 1999 & Samta & 9 & 165.56 & 174.44 & 2.49 & 92.22 & 7.82 & bdl & 5.65 \\
\hline BGD 17 & May 1999 & Samta & 49 & 164.44 & 294.84 & 1.58 & 62.12 & 2.74 & 0.01 & 2.26 \\
\hline BGD 18 & May 1999 & Samta & 61 & 173.33 & * & 1.64 & 65.93 & 2.99 & 0.01 & 2.47 \\
\hline BGD 20 & May 1999 & Jhenidah & 100 & nd & 3.08 & 8.15 & 10.12 & 0.47 & 0.01 & 0.84 \\
\hline BGD 21 & May 1999 & Burir Char & 61 & nd & 7.24 & 2.77 & 7.24 & 0.04 & 0.04 & 0.07 \\
\hline BGD 22 & May 1999 & Burir Char & 152 & nd & * & 0.34 & 1.89 & 0.32 & bdl & 2.56 \\
\hline BGD 23 & May 1999 & Burir Char & 280 & nd & 7733.29 & 1.46 & 0.00 & 0.23 & bdl & 6.59 \\
\hline BGD 24 & May 1999 & Barishal & 335 & nd & 553.14 & bdl & 1.30 & 0.01 & bdl & 0.18 \\
\hline BGD 25 & May 1999 & Barishal & 290 & nd & 160.57 & 0.38 & 1.25 & 0.01 & bdl & 0.17 \\
\hline BGD 26 & May 1999 & Madaripur & 30 & 34.44 & 25.97 & 6.15 & 84.78 & 0.32 & 0.01 & 0.72 \\
\hline BGD 27 & May 1999 & Choto Arjundi & 27 & 376.67 & 204.62 & 16.48 & 159.10 & 3.74 & 0.02 & 1.05 \\
\hline BGD 28 & May 1999 & Mugraoara & $*$ & nd & * & 17.18 & 0.21 & 0.02 & 0.01 & 0.08 \\
\hline BGD 29 & May 1999 & Patalpara & $*$ & 160.00 & 645.68 & 38.16 & 39.05 & 12.12 & 0.12 & 0.73 \\
\hline BGD 30 & May 1999 & Adampur & 91 & nd & 1.04 & 26.30 & 4.14 & 0.03 & 0.00 & 0.06 \\
\hline BGD 31 & May 1999 & Laxmipur & 50 & 1155.56 & 1549.67 & 8.33 & 93.34 & 8.94 & 0.04 & 2.60 \\
\hline BGD 32 & May 1999 & Laxmipur & 40 & 1066.67 & 2057.20 & 11.04 & 110.93 & 7.76 & 0.05 & 4.11 \\
\hline BGD 33 & May 1999 & Laxmipur & 30 & 977.78 & 1902.18 & 11.56 & 140.07 & 9.50 & 0.04 & 3.21 \\
\hline BGD 34 & May 1999 & Laxmipur & 20 & 622.22 & 1734.50 & 18.95 & 81.68 & 5.79 & 0.07 & 2.46 \\
\hline BGD 35 & May 1999 & Laxmipur & 10 & nd & $*$ & 10.19 & 14.31 & 2.07 & 0.16 & 0.46 \\
\hline BGD 36 & May 1999 & Laxmipur & 150 & nd & 2.29 & 22.02 & 56.84 & 0.25 & bdl & 1.33 \\
\hline BGD 37 & January 2000 & Shibganj & 42 & 0.00 & * & 12.87 & 0.00 & 0.00 & 0.01 & 0.84 \\
\hline BGD 38 & January 2000 & Nawabganj & 9.1 & 37.78 & $*$ & 24.75 & 72.05 & 0.26 & 0.01 & 1.79 \\
\hline BGD 39 & January 2000 & Nawabganj & 19.2 & 374.44 & $*$ & 20.04 & 74.81 & 5.77 & 0.04 & 2.12 \\
\hline BGD 40 & January 2000 & Nawabganj & 34 & 52.22 & $*$ & 15.85 & 58.43 & 5.56 & 0.04 & 1.86 \\
\hline BGD 41 & January 2000 & Iswardi & 36 & nd & $*$ & 11.46 & 0.00 & 0.00 & 0.01 & 0.25 \\
\hline BGD 42 & January 2000 & Iswardi & 30 & nd & $*$ & 35.06 & 16.45 & 0.01 & 0.01 & 0.37 \\
\hline BGD 43 & January 2000 & Padma River & 33 & nd & $*$ & 17.86 & 23.49 & 0.02 & 0.00 & 0.58 \\
\hline BGD 44 & January 2000 & Baghail Dotala Sako & 35 & 6.67 & 2.47 & 15.80 & 0.57 & 1.09 & 0.04 & 0.64 \\
\hline BGD 45 & January 2000 & Baghail Dotala Sako & 35 & 7.78 & $*$ & 21.73 & 14.18 & 2.64 & 0.03 & 0.83 \\
\hline BGD 46 & January 2000 & Ruppur & 18.3 & 11.11 & $*$ & 18.66 & 6.44 & 0.35 & 0.02 & 1.16 \\
\hline BGD 47 & January 2000 & Meherpur & 32.3 & nd & * & 4.91 & 0.49 & 0.29 & 0.01 & 1.01 \\
\hline BGD 48 & January 2000 & Refugee Para & 27 & 25.56 & 3.94 & 15.99 & 6.75 & 12.75 & 0.03 & 0.96 \\
\hline BGD 49 & January 2000 & Ghosh Para & 36 & 65.56 & $*$ & 9.11 & 65.29 & 0.91 & 0.02 & 2.25 \\
\hline BGD 50 & January 2000 & Ujjalpur & 40 & 50.00 & $*$ & 12.07 & 75.42 & 5.93 & 0.04 & 2.00 \\
\hline BGD 51 & January 2000 & Ghosh and Refugee & 36 & nd & $*$ & 10.62 & 66.90 & 1.83 & 0.04 & 1.91 \\
\hline BGD 52 & January 2000 & Kustia & 33 & nd & $*$ & 16.40 & 12.53 & 0.02 & 0.01 & 0.60 \\
\hline BGD 53 & January 2000 & Kustia & 37 & 68.89 & 191.13 & 3.10 & 71.77 & 1.48 & 0.02 & 1.87 \\
\hline BGD 54 & January 2000 & Kustia & 35 & nd & * & 3.00 & 0.77 & 1.57 & 0.02 & 0.37 \\
\hline BGD 55 & January 2000 & Paurosabha & 82.3 & 10.00 & $*$ & 18.07 & 2.75 & 0.06 & 0.02 & 0.62 \\
\hline BGD 56 & January 2000 & Kustia Town & 88.4 & 67.78 & * & 9.37 & 18.22 & 0.71 & 0.01 & 0.71 \\
\hline IND 1 & January 2000 & Moyna & 50.3 & 43.33 & 67.06 & 1.44 & 44.63 & 12.53 & 0.03 & 0.65 \\
\hline IND 2 & January 2000 & Moyna & 114 & 8.89 & * & 1.71 & 0.54 & 0.03 & 0.00 & 1.23 \\
\hline IND 3 & January 2000 & Moyna & 47.2 & nd & 2.13 & 22.34 & 0.00 & 0.45 & 0.02 & 0.44 \\
\hline IND 4 & January 2000 & Moyna & 18.3 & 36.67 & 564.96 & 4.22 & 56.53 & 2.42 & 0.02 & 1.67 \\
\hline IND 5 & January 2000 & Moyna & 46 & 64.44 & * & 1.33 & 37.56 & 1.89 & 0.03 & 2.01 \\
\hline IND 6 & January 2000 & Birohi & 18.3 & nd & 221.83 & 4.00 & 53.20 & 1.74 & 0.02 & 2.80 \\
\hline IND 7 & January 2000 & Birohi & 126 & nd & $*$ & 2.88 & 11.44 & 1.19 & 0.02 & 2.63 \\
\hline IND 8 & January 2000 & Birohi & 207 & 6.67 & $*$ & 1.83 & 1.28 & 0.02 & 0.01 & 0.65 \\
\hline IND 9 & January 2000 & Baruipur & 293 & nd & 7.64 & 0.66 & 4.07 & 0.04 & 0.02 & 0.96 \\
\hline DAC 1 & January 2000 & Dhaka & $*$ & nd & $*$ & 0.39 & 0.00 & 0.00 & bdl & 0.12 \\
\hline DAC 2 & January 2000 & Dhaka & $*$ & nd & $*$ & 0.75 & 0.00 & 0.11 & bdl & 0.52 \\
\hline DAC 3 & January 2000 & Dhaka & $*$ & nd & $*$ & 0.49 & 10.72 & 0.01 & bdl & 0.29 \\
\hline
\end{tabular}

${ }^{\text {a }}$ All data are in $\mu \mathrm{mol} / \mathrm{L}$. An asterisk means data were not available; nd is not detected, and bdl is below detection limit. 


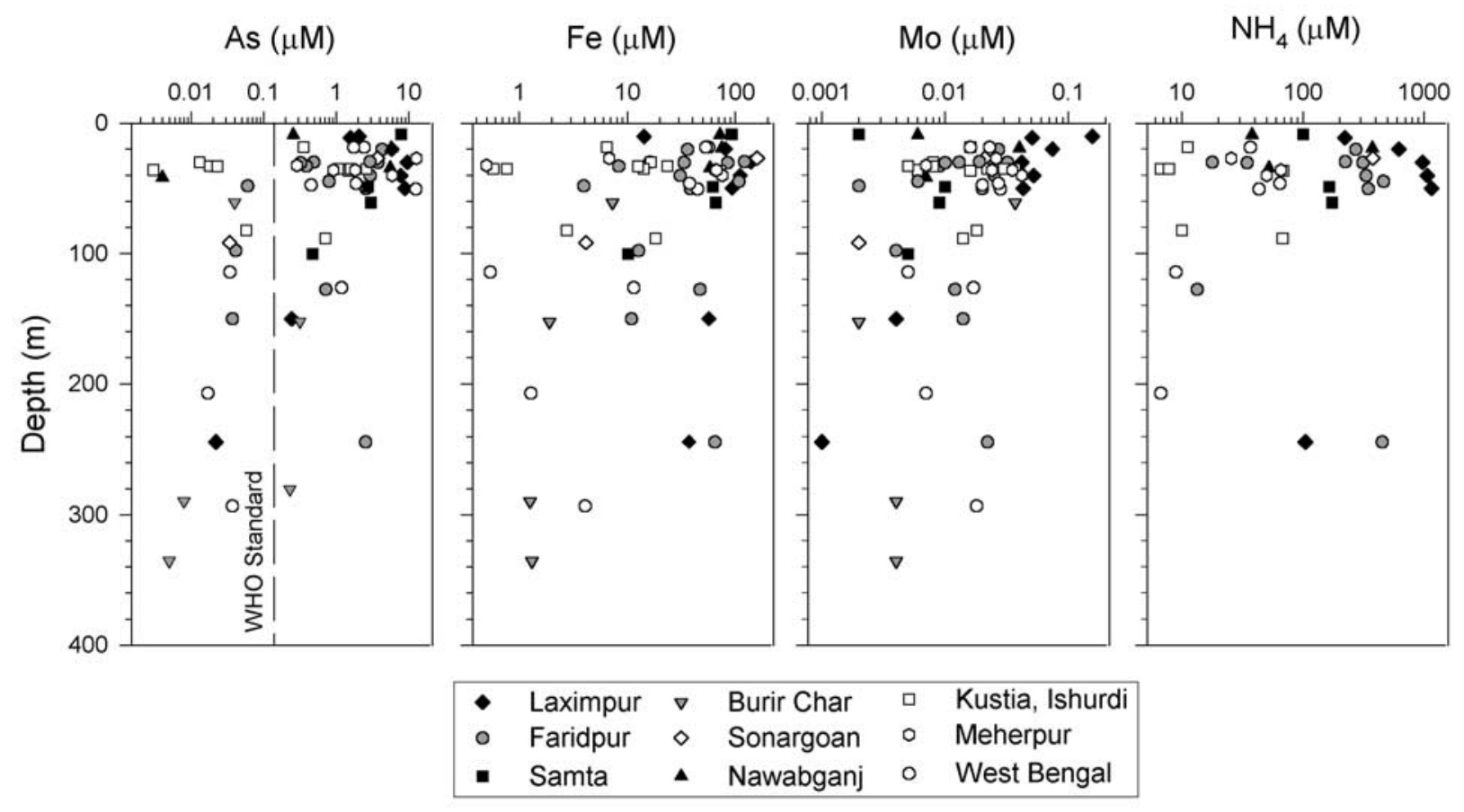

Figure 2. Depth profiles of dissolved $\mathrm{As}, \mathrm{Fe}, \mathrm{Mo}$, and $\mathrm{NH}_{4}$. The groundwater arsenic concentrations above the WHO standard $(0.01 \mathrm{ppm} ; 0.13 \mu \mathrm{M})$ along with elevated levels of iron, molybdenum, and ammonia are concentrated in the shallow wells $(<60 \mathrm{~m})$. The higher levels of As in the deeper wells $(>60 \mathrm{~m})$ are most likely from the wells screening both deep, As-free and shallow, As-rich groundwater.

also found at depths of less than $60 \mathrm{~m}$ in a crude correlation with As-bearing localities.

[18] Several studies have linked the release of As to the dissolution of FeOOH [Nickson et al., 1998; Cummings et al., 1999; Nickson et al., 2000; McArthur et al., 2001]. A positive correlation between dissolved arsenic and iron implies that the arsenic is probably coming from the dissolution of $\mathrm{FeOOH}$, and we confirm a weak positive correlation between $\mathrm{Fe}$ and As in Figure 3. This plot also examines the associations between $\mathrm{As}$ and $\mathrm{NH}_{4}, \mathrm{CH}_{4}$, and Mo because ammonia and methanogenic methane are good indicators of microbial activity in the anoxic groundwater and molybdate, as a redox sensitive oxy-anion, would demonstrate the importance of adsorption and desorption reactions on the sediment surfaces. For all the Bengal Basin wells, arsenic versus methane, iron, molybdenum and ammonia have weak to modest positive correlations $\left(\mathrm{r}^{2}\right.$ ranging from 0.37 to 0.55 ). Note the poor correlations between $\mathrm{As}$ and $\mathrm{Fe}$ when all the samples are included. Some groundwaters have high Fe but low As concentrations suggesting that the simple breakdown of $\mathrm{FeOOH}$ may not be sufficient to explain high levels of dissolved As.

[19] However, when the data from only arsenic laden areas (Laxmipur and Faridpur) are plotted in Figure 4, much stronger correlations occur between $\mathrm{As}$ and $\mathrm{CH}_{4}, \mathrm{Fe}$, and $\mathrm{NH}_{4}\left(\mathrm{r}^{2}\right.$ ranging from 0.8 to 0.9$)$. In the Laxmipur water samples, the molar ratio of $\mathrm{As} / \mathrm{Fe}$ ranges from 0.070 to 0.144 with an average of $0.090 \pm 0.032$. The groundwater at Faridpur $(20-50 \mathrm{~m})$ has a comparable As/Fe ratio $(0.099 \pm$ 0.02 ) that varies between 0.067 and 0.119 . The As-Mo relation indicates that adsorption-desorption reactions may also play a significant role in controlling the final dissolved concentrations of As, Fe, and Mo. At Laxmipur and Faridpur, there are strong positive correlations $\left(\mathrm{r}^{2}=0.9\right)$ between arsenic and methane and ammonia with the highest levels occurring at less than $60 \mathrm{~m}$ deep at the two multilevel sites (Figure 4). The As- $\mathrm{CH}_{4}$ and $\mathrm{As}-\mathrm{NH}_{4}$ correlations indicate that both methanogens and other bacteria are active in the anoxic groundwater and suggest that a source of organic carbon is essential to the overall release of arsenic. When combined with the iron data, the associations between arsenic and methane, ammonia, and iron support the microbially mediated reductive dissolution of $\mathrm{FeOOH}$ as the dominant reaction for arsenic release into groundwater. There is a strong correlation $\left(\mathrm{r}^{2}=0.8\right)$ between dissolved As and $\mathrm{Fe}$ in the Faridpur and Laxmipur groundwater samples with greater than $30 \mu \mathrm{mol} / \mathrm{L} \mathrm{CH}_{4}$. It seems that methane is a key indicator of microbial activity and signifies the importance of organic carbon decomposition to the release of As. In the shallow wells, water samples have been stripped of their atmospheric gases from the high levels of biogenic methane. Since there is no ${ }^{4} \mathrm{He}$ associated with these shallow samples (Table 2) and thermogenic methane has measurable levels of helium (>10 ppm), methanogenic microbes are most likely producing the methane in this reducing environment.

[20] Groundwater residence times $\left({ }^{3} \mathrm{He} /{ }^{3} \mathrm{H}\right.$ age dating) can provide important information about the arsenic buildup and the possible relation to subsurface stratigraphy. By using ${ }^{3} \mathrm{He} /{ }^{\beta} \mathrm{H}$ groundwater ages, we can estimate the recharge rate to the aquifers and subsurface travel time [Solomon et al., 1992, 1993]. The calculated recharge rate to the Bengal Basin groundwater is $60 \pm 20 \mathrm{~cm} / \mathrm{yr}$. The groundwater vertical velocity ranges from $3 \mathrm{~m} / \mathrm{yr}$ in the 

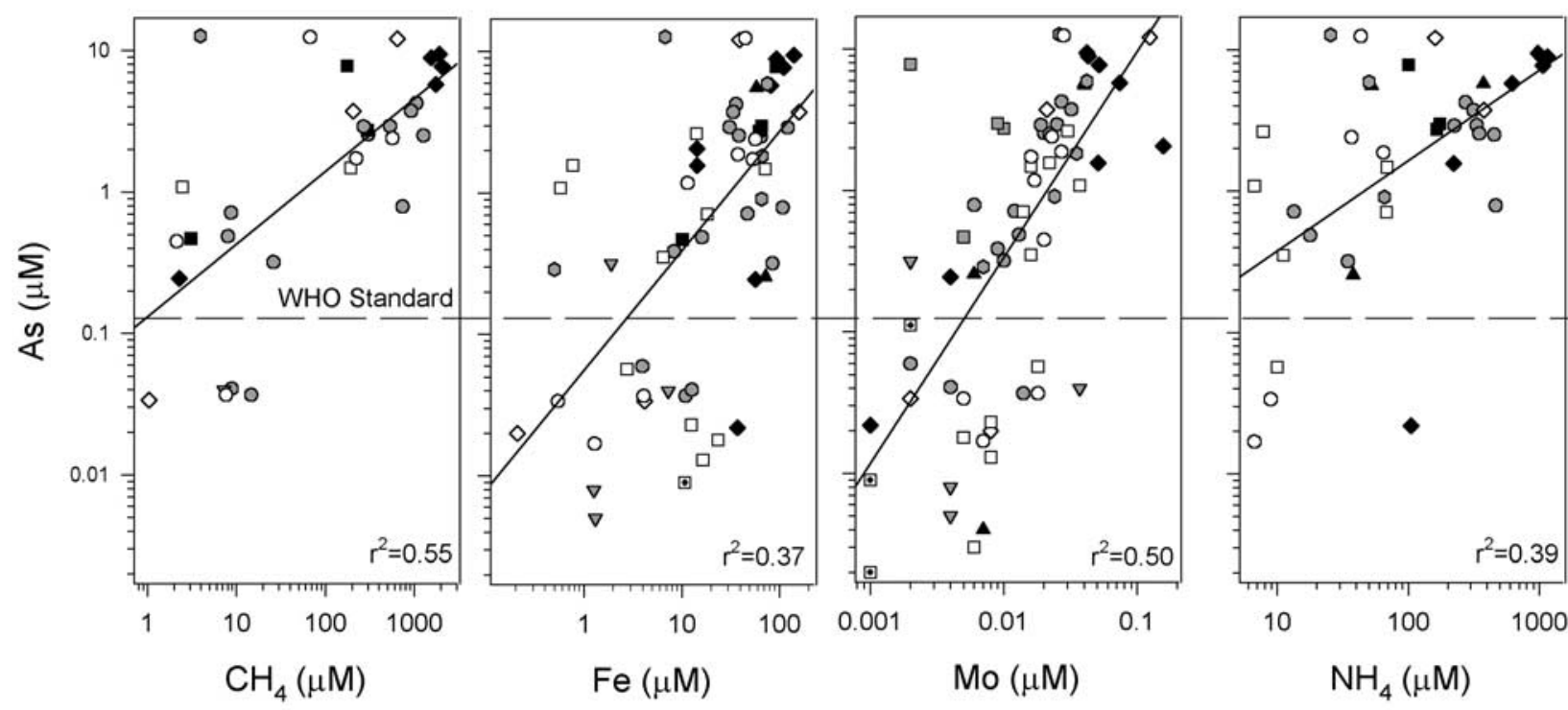

\begin{tabular}{llllll}
\hline & Laximpur & $\nabla$ & Burir Char & $\square$ & Kustia, Ishurdi \\
- Faridpur & $\diamond$ & Sonargoan & $\circ$ & Meherpur \\
- Samta & $\star$ & Nawabganj & $\circ$ & West Bengal \\
& & Dhaka & & \\
\hline
\end{tabular}

Figure 3. Dissolved As versus $\mathrm{CH}_{4}, \mathrm{Fe}, \mathrm{Mo}$, and $\mathrm{NH}_{4}$. Dissolved arsenic levels from all the wells in the Bengal Basin are plotted against methane, iron, molybdenum, and ammonia. There are only weak to modest correlations between arsenic and methane, iron, molybdenum, and ammonia.

active flow system to $<0.5 \mathrm{~m} / \mathrm{yr}$ in the low conductivity sediments of Laxmipur and Faridpur. This sizeable contrast in vertical velocities suggests that a complex stratigraphy of high and low conductivity layers exist within the subsurface of the Ganges-Brahmaputra floodplain, which is consistent with its geologic history [Lindsay et al., 1991; Umitsu, 1993; Uddin and Lundberg, 1998; Goodbred and Kuehl, 2000; Dowling et al., submitted manuscript, 2002]. A schematic cross section from A-A' (of Figure 1) is shown in Figure 5. For a more complete discussion about groundwater ages and vertical velocities of the Bengal Basin, please refer to Dowling et al. (submitted manuscript, 2002).

[21] The samples from the Laxmipur and Faridpur sites contain tritium only in the most shallow 10-20 m interval (Table 2). The other groundwater samples at Laxmipur and Faridpur are tritium-free $(<0.15 \mathrm{~T}$. U.) below $20 \mathrm{~m}$, indicative of low permeability sediments and groundwater residence times of more than 60 years. This older ( $>60$ years) shallow groundwater contains elevated concentrations of arsenic, methane, and ammonia but little phosphate and challenges any proposed link between arsenic and recent applications of phosphate-rich fertilizer [Acharyya et al., 1999, 2000]. Fine-grained sediments, mostly silt and very fine sand, dominate the depositional environment in the Laxmipur and Faridpur regions and are suggested as the dominant source of the As and $\mathrm{CH}_{4}$.

[22] There are several deeper wells within the upper aquifer (Table 2; $100 \mathrm{~m}$ to $250 \mathrm{~m}$; BGD-6, 9, 14, 15, 29, 36 ) that have residence times of greater than 60 years (shaded triangles in Figure 5). They have no tritium and a moderate concentration of radiogenic helium $(10-50 \mu \mathrm{cc} / \mathrm{kg})$. Model ages, using the measured radiogenic ${ }^{4} \mathrm{He}$ accumulation rate from the aquifer solids to the groundwater $\left(0.02 \mu \mathrm{cc} / \mathrm{kg}_{\text {water }} /\right.$ yr), suggest groundwater residence times of $100-500$ years (Dowling et al., submitted manuscript, 2002). In three cases (BGD 6, 9, and 36), the wells lie beneath the arsenic, methane-rich clusters at Faridpur and Laxmipur and yet the wells do not contain elevated levels of either methane or arsenic. In other wells with residence times of greater than 60 years (such as the shallow samples at Laxmipur and Faridpur along with BGD 14, 15 and 29), As has a clear association with $\mathrm{CH}_{4}$ but not with age.

[23] In the very deepest parts of the groundwater systems $(>200 \mathrm{~m})$, there is evidence of long groundwater residence times (>1000 yrs) with elevated levels of ${ }^{4} \mathrm{He}$ and $\mathrm{CH}_{4}$ and background concentrations of As $(<10 \mathrm{nM})$. Although the $\delta^{13} \mathrm{C}$ of this methane was not analyzed, the most likely source of this methane is from thermogenic breakdown of deep organic matter in the Bengal Fan. The association of ${ }^{4} \mathrm{He}$ and $\mathrm{CH}_{4}$ is more typical of thermogenic rather than biogenic natural gas. Groundwater in this deeper zone (see Figure 5) is partially separated from the shallow $(<200 \mathrm{~m})$ system by an aquitard of marine clay (estimated to be $>40,000$ years based on the sedimentation rate of $5 \mathrm{~mm} /$ yr). Based on the accumulation of helium and methane in this lower aquifer, the recharge to this lower unit is estimated at less than $1 \mathrm{~cm} / \mathrm{yr}$. With the exception of BGD-8 $(\mathrm{As}=2.53 \mu \mathrm{M})$ and BGD-23 $(\mathrm{As}=0.23 \mu \mathrm{M})$, all deep wells $(>200 \mathrm{~m})$ contain background levels of As. Based on the chemistry of BGD-8, there is reason to believe that the wells screen both shallow, As-rich, $\mathrm{CH}_{4}$-rich water (30-50m) and deep He-rich, As and $\mathrm{CH}_{4}$-free waters. There is an adjacent well, BGD-9, that taps only As-free, deep 


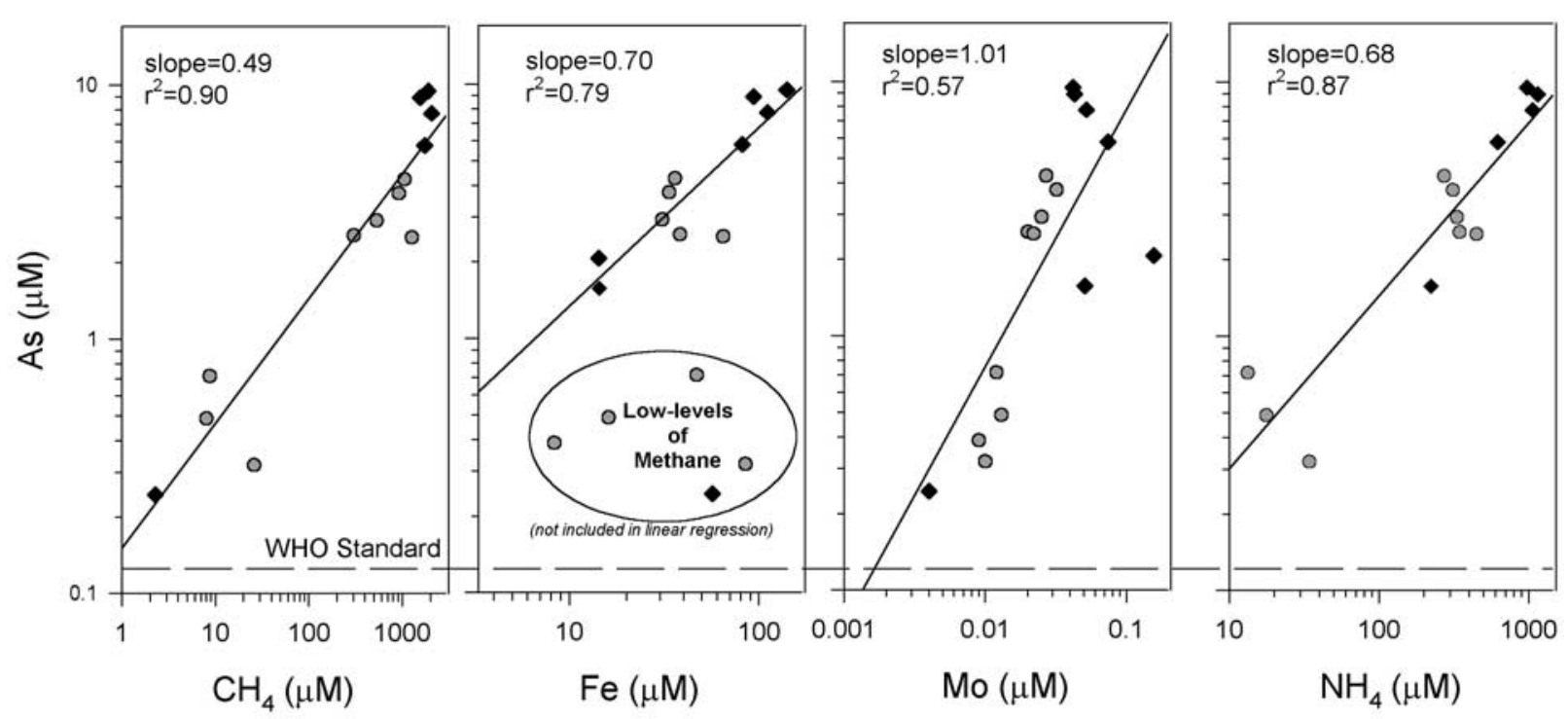

- Laximpur

- Faridpur

Figure 4. Dissolved As versus $\mathrm{CH}_{4}, \mathrm{Fe}, \mathrm{Mo}$, and $\mathrm{NH}_{4}$ in Faridpur and Laxmipur. Dissolved arsenic levels from wells located in Faridpur and Laxmipur are plotted against methane, iron, molybdenum, and ammonia. There are reasonable correlations $\left(\mathrm{r}^{2}=0.8-0.9\right)$ between arsenic and methane, iron, and ammonia. The As- $\mathrm{CH}_{4}$ and As- $-\mathrm{NH}_{4}$ correlations indicate that there are active microbes in the anoxic groundwater. The $\mathrm{As}, \mathrm{CH}_{4}$, and $\mathrm{NH}_{4}$ associations combined with the $\mathrm{Fe}$ data support bacterial reduction of $\mathrm{FeOOH}$ as the main release mechanism of As into the groundwater. The modest relation with Mo $\left(\mathrm{r}^{2}=\right.$ 0.6 ) indicates that adsorption reactions on sediment surfaces influence the trace metal concentrations in the groundwater. The samples experiencing low levels of microbial activity (based on $\mathrm{CH}_{4}$ levels) are excluded from the As-Fe correlation.

groundwater and has the same helium concentration and isotope ratio as BGD-6 and BGD-8.

\subsection{Sediment Data}

[24] Sediments influence aqueous chemistry of the ground and river water via adsorption and desorption reactions on sediment surfaces (e.g. grain-size) and through weathering of the sediment (e.g. mineralogy). To fully examine the processes that control the dissolved levels of $\mathrm{As}, \mathrm{Ba}, \mathrm{Fe}, \mathrm{Mo}$, and $\mathrm{Mn}$ in the groundwater, we measured the adsorbed trace metals on river sediments (northern and southern Ganges, northern and southern Brahmaputra), and drill core samples from Laxmipur, Bangladesh (Figure 1) by the standard oxalate extraction method. The oxalate procedure [McKeague, 1978] removes adsorbed cations and breaks down $\mathrm{Mn}$ and $\mathrm{Fe}$ oxy-hydroxides. Table 3a displays the $\mathrm{As}, \mathrm{Ba}, \mathrm{Fe}$, and $\mathrm{Mn}$ (Mo is not included because the adsorbed concentrations are below the detection limit) concentrations adsorbed on bulk river sediments (RW-53 and RW-54), river mica separates (Rishikesh and Guwahati), and three fractions of the Laxmipur core (bulk, finegrained, and mica). Table $3 \mathrm{~b}$ presents the $\mathrm{As}, \mathrm{Ba}, \mathrm{Fe}$, and Mn data from the organic fraction of the river and Laxmipur core bulk samples and the digestion of the river fine-grained fraction, river mica separates, and the Laxmipur core finegrained and mica fractions. In some of the drill core $(23 \mathrm{~m}$ and $39 \mathrm{~m}$ ) and river (RW-53 and RW-54) samples, there was insufficient mica for the ammonium oxalate extraction. The exchangeable and adsorbed trace elements extraction procedure did not dissolve the carbonates because there was no measurable calcium $(<0.05 \mathrm{ppm})$ in the oxalate supernatant. In the Laxmipur oxalate extract, magnesium was the dominant cation present with a lesser amount of potassium and sodium. The river sediment supernatant had magnesium as the only measurable cation.

[25] Figure 6 displays the results of select trace elements (As, $\mathrm{Ba}, \mathrm{Fe}$, and $\mathrm{Mn}$ ) adsorbed on the Laxmipur sediment core and dissolved in the Laxmipur groundwater versus depth. The organic fraction is not included because the average As in the organic fraction of the Laxmipur core is $0.66 \pm 0.16 \mu \mathrm{mol} / \mathrm{L}(\mathrm{n}=3)$ and less than $5 \%$ of the amount found in the oxalate extraction. Two $\mathrm{C}_{\text {organic }}$ samples (Lax23 and Lax-48) have As levels below the detection limit, suggesting that the oxidation of organic carbon itself $(<0.4 \%$ for all depths), although essential to the As release mechanisms, is not a contributor itself in the overall As budget in the Bengal Basin (Table 3b). The groundwater As, $\mathrm{Ba}$, and $\mathrm{Fe}$ increase with depth, until $30 \mathrm{~m}$ where fairly constant values are reached. Manganese does not show a similar trend suggesting that Mn quickly re-adsorbs onto the aquifer protolith and the breakdown of $\mathrm{Mn}$ oxides is probably not an important source of As or, alternatively, arsenic is released by the breakdown of manganese oxides but remains in solution while $\mathrm{Mn}$ re-adsorbs. The adsorbed 
Table 2. Dissolved Gas Data and Ages of the Bengal Basin Groundwaters ${ }^{\mathrm{a}}$

\begin{tabular}{|c|c|c|c|c|c|c|c|c|c|c|c|}
\hline $\begin{array}{l}\text { Sample } \\
\text { Name }\end{array}$ & Sample Location & Depth, m & $\begin{array}{l}\text { Total }{ }^{4} \mathrm{He} \\
\quad \mu \mathrm{cc} / \mathrm{kg}\end{array}$ & $\begin{array}{l}\text { Radiogenic } \\
{ }^{4} \mathrm{He}, \mu \mathrm{cc} / \mathrm{kg}\end{array}$ & $\begin{array}{c}\mathrm{Ne}, \\
\mu \mathrm{cc} / \mathrm{kg}\end{array}$ & $\begin{array}{l}\mathrm{N}_{2} \\
\mathrm{cc} / \mathrm{kg}\end{array}$ & $\begin{array}{c}\mathrm{Ar} \\
\mathrm{cc} / \mathrm{kg}\end{array}$ & $\begin{array}{l}\mathrm{CH}_{4} \\
\mathrm{cc} / \mathrm{kg}\end{array}$ & $\mathrm{R} / \mathrm{Ra}$ & ${ }^{3} \mathrm{H}, \mathrm{TU}$ & $\begin{array}{c}{ }^{3} \mathrm{He} /{ }^{3} \mathrm{H} \\
\text { Age, years }\end{array}$ \\
\hline BGD 2 & Sonapur & 11 & $*$ & $*$ & $*$ & $*$ & $*$ & $*$ & $*$ & 2.4 & $<20$ \\
\hline BGD 3 & Faridpur & 20 & 18.6 & 9.1 & 62.2 & 5.4 & 0.2 & 23.6 & 0.90 & $<0.15$ & $>80$ \\
\hline BGD 4 & Faridpur & 30 & 18.9 & 0.0 & 77.1 & 5.8 & 0.2 & 20.6 & 0.94 & $<0.15$ & $>80$ \\
\hline BGD 5 & Faridpur & 40 & 25.1 & 3.6 & 103.2 & 6.6 & 0.2 & 11.9 & 0.92 & $<0.15$ & $>80$ \\
\hline BGD 6 & Faridpur & 150 & 99.1 & 72.9 & 106.5 & 8.1 & 0.2 & 0.3 & 0.53 & $<0.15$ & $>80$ \\
\hline BGD 7 & Faridpur & 50 & 36.9 & 2.9 & 140.8 & 8.9 & 0.2 & 6.8 & 0.96 & $<0.15$ & $>80$ \\
\hline BGD 8 & Faridpur & 244 & 53.2 & 29.9 & 109.8 & 7.6 & 0.2 & 28.4 & 0.55 & $<0.15$ & $>80$ \\
\hline BGD 9 & Faridpur & 98 & 53.6 & 28.9 & 119.4 & 7.6 & 0.2 & 0.2 & 0.56 & $<0.15$ & $>80$ \\
\hline BGD 10 & Ahladipur & 30 & 39.4 & -1.9 & 171.0 & 16.1 & 0.3 & 0.2 & 2.51 & 8.4 & 28.5 \\
\hline BGD 11 & Rajbari & 48 & $*$ & $*$ & $*$ & $*$ & $*$ & $*$ & $*$ & 4.2 & $<20$ \\
\hline BGD 12 & Rajbari & 33 & $*$ & $*$ & $*$ & $*$ & $*$ & $*$ & $*$ & 6.2 & 30 \\
\hline BGD 13 & Rajbari & 127 & 66.2 & -1.0 & 260.9 & 14.6 & 0.3 & 0.2 & 1.03 & 0.5 & 14.7 \\
\hline BGD 14 & Talma & 44 & 55.9 & 28.7 & 101.0 & 5.8 & 0.2 & 16.4 & 0.49 & $*$ & $*$ \\
\hline BGD 15 & Nagarkanda & 29 & 52.1 & 5.0 & 184.2 & 10.9 & 0.3 & 6.0 & 0.85 & 0.3 & $>80$ \\
\hline BGD 16 & Samta & 9 & 26.5 & 3.2 & 109.6 & 9.7 & 0.2 & 3.9 & 1.84 & 8.4 & 17.9 \\
\hline BGD 17 & Samta & 49 & 44.6 & -5.6 & 191.4 & 11.2 & 0.3 & 6.6 & 1.03 & 0.2 & 40.1 \\
\hline BGD 18 & Samta & 61 & $*$ & $*$ & $*$ & $*$ & $*$ & $*$ & $*$ & $<0.15$ & $>80$ \\
\hline BGD 20 & Jhenidah & 100 & 65.6 & -6.5 & 271.9 & 14.5 & 0.3 & 0.1 & 1.78 & 5.8 & 30.3 \\
\hline BGD 21 & Burir Char & 61 & 51.7 & -2.7 & 210.8 & 11.5 & 0.3 & 0.2 & 2.39 & 4.8 & 40.0 \\
\hline BGD 22 & Burir Char & 152 & $*$ & $*$ & $*$ & $*$ & $*$ & $*$ & * & $<0.15$ & $*$ \\
\hline BGD 23 & Burir Char & 280 & 5302.1 & 5276.0 & 116.8 & 10.7 & 0.3 & 173.2 & 0.09 & $<0.15$ & $>100$ \\
\hline BGD 24 & Barishal & 335 & 3277.8 & 3109.4 & 610.7 & 36.7 & 0.6 & 12.4 & 0.30 & $<0.15$ & $>100$ \\
\hline BGD 25 & Barishal & 290 & 895.2 & 845.1 & 200.0 & 14.6 & 0.2 & 3.6 & 0.29 & $<0.15$ & $>100$ \\
\hline BGD 26 & Madaripur & 30 & 53.8 & -5.1 & 233.1 & 14.0 & 0.3 & 0.6 & 1.05 & 3.4 & 8.4 \\
\hline BGD 27 & Choto Arjundi & 27 & 40.1 & -6.7 & 169.2 & 8.9 & 0.2 & 4.6 & 1.17 & 0.8 & 36.6 \\
\hline BGD 28 & Mugraoara & $*$ & $*$ & $*$ & $*$ & $*$ & $*$ & $*$ & $*$ & $<0.15$ & $*$ \\
\hline BGD 29 & Patalpara & $*$ & 51.0 & 12.4 & 144.1 & 9.0 & 0.2 & 14.5 & 0.76 & 0.3 & 8 \\
\hline BGD 30 & Adampur & 91 & 311.5 & 265.8 & 184.9 & 11.6 & 0.3 & 0.0 & 0.45 & $<0.15$ & $>80$ \\
\hline BGD 31 & Laxmipur & 50 & 3.5 & $8.6^{\mathrm{b}}$ & 8.6 & 1.1 & 0.0 & 34.7 & 0.76 & 0.4 & $>80$ \\
\hline BGD 32 & Laxmipur & 40 & 3.9 & $8.9^{\mathrm{b}}$ & 8.9 & 1.4 & 0.1 & 46.1 & 0.66 & 0.2 & $>80$ \\
\hline BGD 33 & Laxmipur & 30 & 3.8 & $8.9^{\mathrm{b}}$ & 8.4 & 1.5 & 0.1 & 42.6 & 0.73 & $<0.15$ & $>80$ \\
\hline BGD 34 & Laxmipur & 20 & 8.8 & 1.3 & 23.0 & 2.4 & 0.1 & 38.9 & 0.79 & 0.2 & $>80$ \\
\hline BGD 35 & Laxmipur & 10 & $*$ & $*$ & $*$ & $*$ & $*$ & $*$ & $*$ & 2.8 & $<20$ \\
\hline BGD 36 & Laxmipur & 150 & 73.2 & 26.3 & 180.6 & 9.8 & 0.2 & 0.1 & 0.59 & 0.4 & 51.9 \\
\hline BGD 40 & Nawabganj & 34 & $*$ & $*$ & $*$ & $*$ & $*$ & $*$ & $*$ & $<0.15$ & $*$ \\
\hline BGD 44 & Baghail Dotala Sako & 35 & 67.3 & 1.5 & 260.7 & 16.4 & 0.4 & 0.1 & 1.45 & 5.3 & 27.1 \\
\hline BGD 48 & Refugee Para & 27 & 53.2 & -4.5 & 223.8 & 14.1 & 0.3 & 0.1 & 1.32 & 2.7 & 23.9 \\
\hline BGD 53 & Kustia & 37 & 82.0 & 25.6 & 231.8 & 18.5 & 0.4 & 4.3 & 1.00 & $<0.15$ & $>80$ \\
\hline IND 1 & Moyna & 50 & 57.5 & -1.9 & 228.2 & 13.5 & 0.3 & 1.5 & 1.41 & 3.3 & 28.5 \\
\hline IND 3 & Moyna & 47.2 & 60.3 & 2.0 & 227.0 & 14.0 & 0.3 & 0.0 & 1.18 & 0.6 & 46.3 \\
\hline IND 4 & Moyna & 18.3 & 78.3 & -4.1 & 297.4 & 15.1 & 0.3 & 12.7 & 1.15 & 1.8 & 23.0 \\
\hline IND 6 & Birohi & 18.3 & 40.4 & -2.2 & 167.2 & 10.4 & 0.2 & 5.0 & 1.85 & 3.7 & 32.1 \\
\hline IND 9 & Baruipur & 293 & 254.6 & 188.5 & 261.4 & 15.4 & 0.4 & 0.2 & 0.37 & $<0.15$ & $>100$ \\
\hline
\end{tabular}

${ }^{a}$ The sample locations are shown in Figure 1. An asterisk means data were not available.

${ }^{\mathrm{b}}$ See explanation in Dowling et al. (submitted manuscript, 2002).

As, Ba, Fe, and Mn have comparable patterns with depth with the exception of $\mathrm{Ba}$ at the surface. The river sediments with their high values of adsorbed $\mathrm{Ba}$ can easily supply the barium to the groundwater through desorption (Dowling et al., submitted manuscript, 2002). However, only active weathering of the aquifer protolith can provide the As, Fe, and $\mathrm{Mn}$ to the groundwater.

[26] Figure 6 clearly demonstrates the role that grain size plays in controlling the solid phase distribution of many trace elements. In the oxalate extraction of the sediment, the bulk samples of the Laxmipur core have an average As concentration of $35 \pm 14 \mu \mathrm{mol} / \mathrm{kg}$ and a range from 12.5 to 51.4 $\mu \mathrm{mol} / \mathrm{kg}$ whereas the river sediment averages $26.5 \pm 8 \mu \mathrm{mol} /$ $\mathrm{kg}$ of As and varies between 20.6 and $32.4 \mu \mathrm{mol} / \mathrm{kg}$. The average arsenic on the fine-grained sediment samples $(<5$ $\mu \mathrm{m})$ is about five times higher $(165 \pm 116 \mu \mathrm{mol} / \mathrm{kg})$, and the concentrations vary between 50.9 and $337.3 \mu \mathrm{mol} / \mathrm{kg}$. The pattern for As with depth is a direct function of grain size and surface area in the bulk and fine-grained fractions. The major drop in $\mathrm{As}, \mathrm{Ba}, \mathrm{Fe}$, and $\mathrm{Mn}$ seen at $39 \mathrm{~m}$ corresponds to a sandier interval that contains mostly quartz, smaller amount of mica, and fewer clay-sized particles $(<5 \mu \mathrm{m})$. The amount of fine-grained material in the sediment influences the overall concentration of the adsorbed trace metal in the bulk sediment.

[27] We use As-Fe molar ratios to examine the correlations between $\mathrm{As}$ and $\mathrm{Fe}$ in the solid phase as well as in solution. In most environments $(\mathrm{pH}<8.5)$, iron oxy-hydroxides have a positive surface charge and will preferentially adsorb anions (like $\mathrm{AsO}_{4}^{3-}$ ). The adsorbed and dissolved iron-arsenic ratios should be similar if the sources and processes that affect the solubility and adsorption of As and $\mathrm{Fe}$ are the same. Typically, manganese-arsenic ratios are not applicable since manganese oxides are often negatively charged and will adsorb cations. However, Mn oxides have been known to adsorb arsenic since the surface charge can be altered by cation adsorption eventually leading to a positive charge [Moi and Wai, 1994] and could be a minor source of As. Figure 7 demonstrates the general correlation $\left(\mathrm{r}^{2}=0.72\right)$ between adsorbed iron and adsorbed arsenic in the river and 


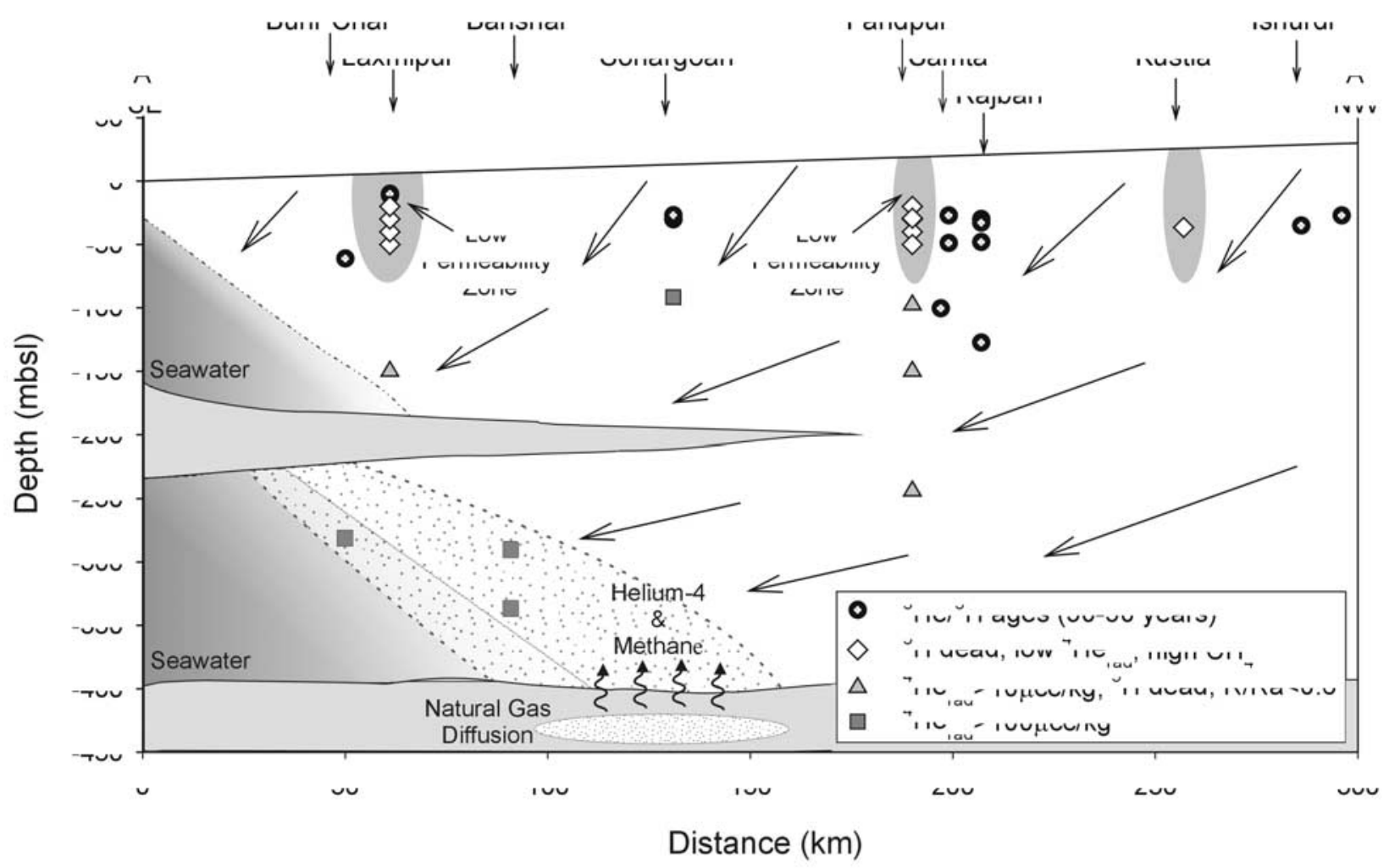

Figure 5. Schematic cross section of groundwater flow in the Bengal Basin along the NW-SE (A-A') line. All wells are projected to the A-A $\mathrm{A}^{\prime}$ line in Figure 1. There are many municipal wells (up to $150 \mathrm{~m}$ ) that contain tritium and have a ${ }^{3} \mathrm{He} /{ }^{3} \mathrm{H}$ groundwater age. Shallow wells at Laxmipur, Faridpur, and Kustia are tritium dead with high biogenic methane. Deeper wells in the upper aquifer, with no tritium and moderate amounts of radiogenic ${ }^{4} \mathrm{He}$, are more than 100 years old. In the lower aquifer, the groundwater has no tritium, elevated methane and helium concentrations, and residence times of greater than 1000 years.

core sediments signifying that the sources of As and $\mathrm{Fe}$ in all solid phases (bulk, fine-grained, and mica) at a given depth may be the same- the dissolution of $\mathrm{FeOOH}$. Overall, the bulk sediment has the lowest As and Fe levels (e.g. the sandy Lax-39-B) and the fine-grained material has the highest AsFe concentrations (e.g. Lax-49-F), which is indicative of the influential role that grain size plays in trace metal concentrations.

[28] Figure 8 displays the adsorbed As/Fe molar ratios of the river and core sediments plotted against depth. The average ratio of the river bulk $(0.0017 \pm 0.0006)$ is similar to that of the river fine-grained $(0.0016 \pm 0.0001)$ fraction. The As/Fe molar ratios of the Laxmipur core fractions (bulk and fine-grained) vary between 0.0005 and 0.0023 with a pronounced decrease with depth resulting from the older, deeper sediments having more fresh water flowing through and removing some of the adsorbed As. In comparison, the British Geological Survey and Mott MacDonald Ltd. [1999] found that the sediments (from $3 \mathrm{~m}$ to $150 \mathrm{~m}$ deep) in Nawabganj, an arsenic hotspot in northwest Bangladesh, have generally lower and more variable As/Fe molar ratios between 0.0001 and 0.0019 . The variability may relate to the age and hydraulic conductivity of the sediments.

[29] Even though the Laxmipur sediment is dominated by iron-stained quartz, there is considerable mica $(5-15 \%$ of the samples), partially altered to vermiculite, found in the sediment. The major and trace element chemistry data imply that the weathering of the mica can have a significant impact on the groundwater chemistry. The average exchangeable arsenic in the Laxmipur mica separates (grain size: $150-250 \mu \mathrm{m}$ ) is $53.6 \pm 4 \mu \mathrm{mol} / \mathrm{kg}$ which is slightly higher than the bulk sediment but much lower than the finegrained sediments (Tables $3 a$ and $3 b$ ) and is most likely related to the $\mathrm{FeOOH}$ coatings on the mica grains. However, the complete digestion of Laxmipur mica after the oxalate extraction shows elevated levels of arsenic (average: $239.8 \pm 73 \mu \mathrm{mol} / \mathrm{kg} ; 17.99 \mathrm{ppm}$ ) or about five times the fine-grained sediment. Thus weathering can provide an additional source of As to the groundwater via silicate weathering. Pristine mica from both northern river sediments (northern Ganges River (Rishikesh, India) and northern Brahmaputra (Guwahati, India)) contains a sizeable reservoir of both extractable As and total As. The Rishikesh mica has $\sim 14$ times more extractable arsenic than the Guwahati mica (294.8 versus $21.5 \mu \mathrm{mol} / \mathrm{kg}$ ) but the difference in "structural" As (digestion after oxalate extraction) is considerably less (239 versus $120 \mu \mathrm{mol} / \mathrm{kg}$ ). Based on the As concentrations and the percentage of mica in the sediment, the weathering of this arsenic-laden mica throughout the GBR floodplain may supply a significant portion of the 


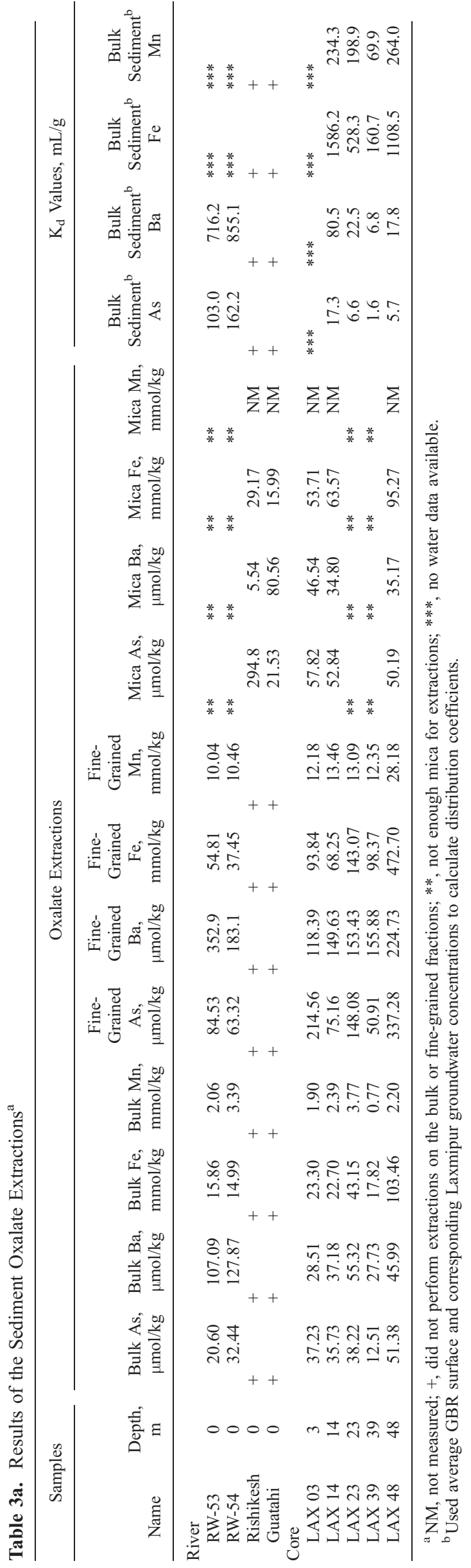




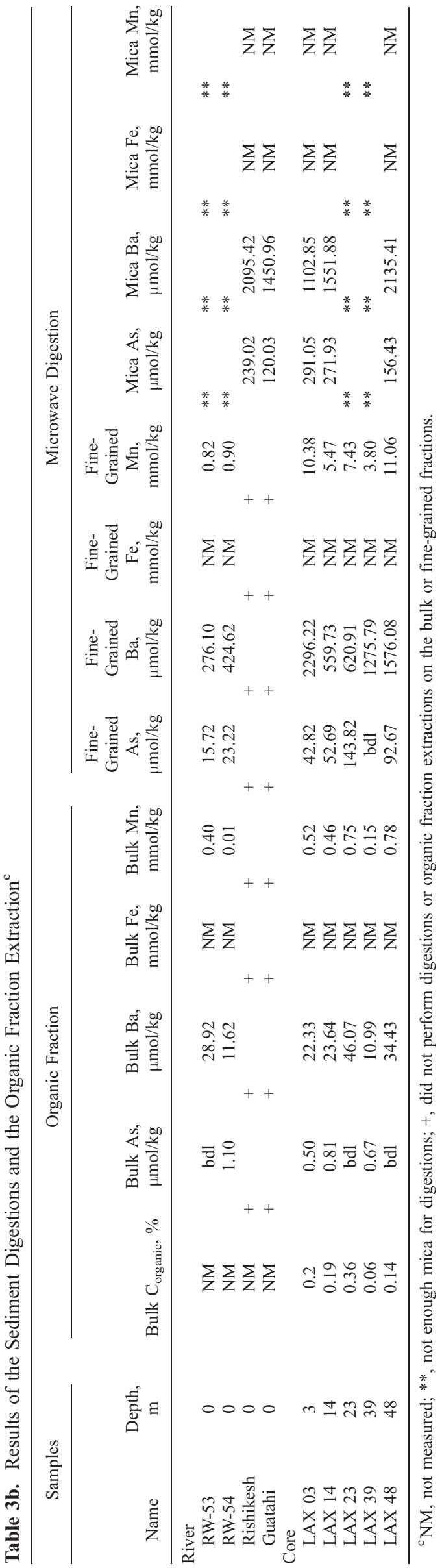


GROUNDWATER

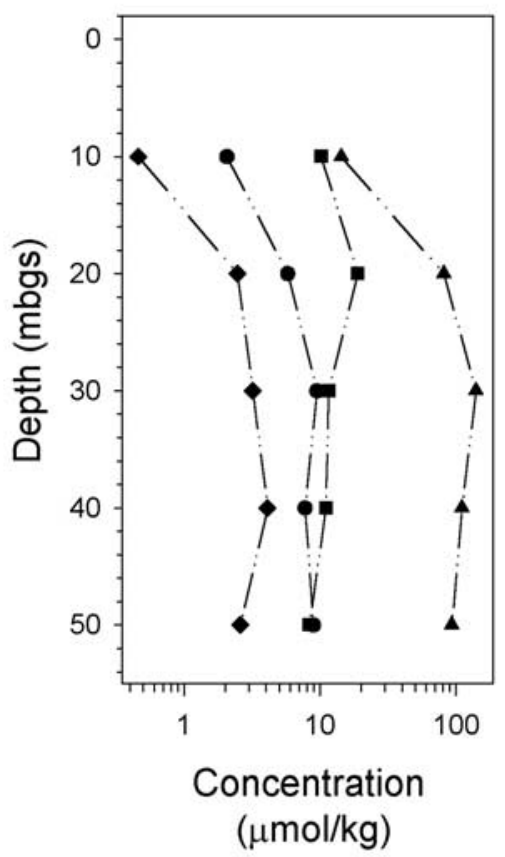

Dissolved As

Dissolved Ba
BULK FRACTION

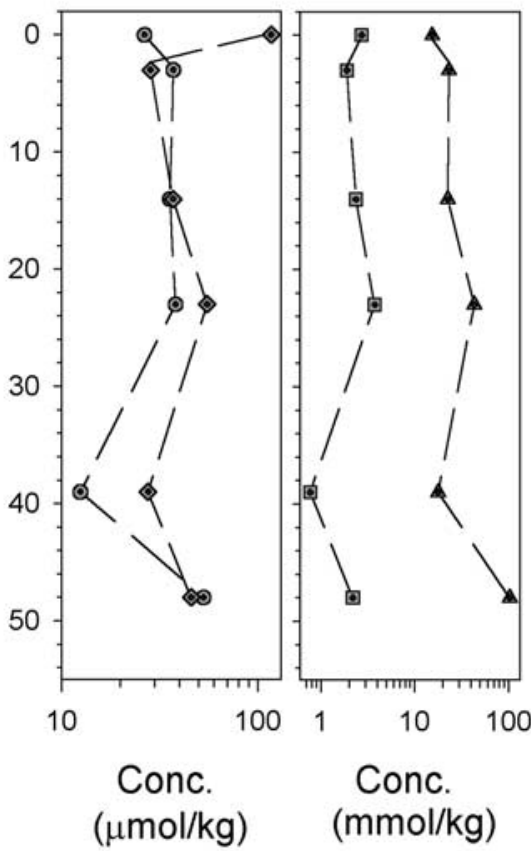

- Adsorbed As $\square$ Adsorbed Mn
FINE-GRAINED SIZE

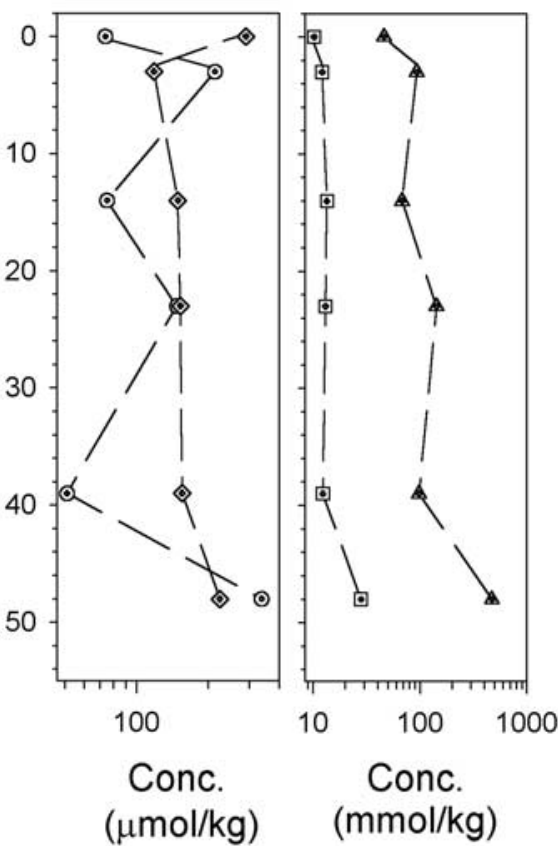

○ Adsorbed As @ Adsorbed $\mathrm{Mn}$

Figure 6. Groundwater and sediment oxalate extraction data plotted against depth at Laxmipur, Bangladesh. Select dissolved and adsorbed data from the water and sediment oxalate extraction analyses (arsenic, barium, iron, and manganese) are plotted against depth at Laxmipur. The concentrations of dissolved $\mathrm{As}, \mathrm{Fe}, \mathrm{Mn}$, and $\mathrm{Ba}$ are 5 times less than the adsorbed bulk fraction. Adsorbed $\mathrm{As}, \mathrm{Fe}$, and $\mathrm{Mn}$ display a similar trend with one another while barium does not. Grain size plays an important role in controlling the concentrations of trace metals dissolved in the groundwater and adsorbed onto sediment. The fine-grained sediment shows the same pattern as the bulk and mica; however, the patterns are more pronounced and the concentrations are higher. The drop in the adsorbed metals seen at $39 \mathrm{~m}$ corresponds to a sandier interval in the drill core.

arsenic that ultimately adsorbs on the $\mathrm{FeOOH}$, thus making it the definitive source of arsenic released to the groundwater. However, we cannot easily distinguish between the two possible sources of arsenic: (1) the arsenic adsorbed onto $\mathrm{FeOOH}$ after weathering out of high-arsenic mica in the aquifer, (2) the arsenic from As-bearing iron oxyhydroxides that flocculated at the seawater/freshwater interface.

\section{Discussion}

\subsection{Microbial Activity}

[30] From the analysis of the correlation plots (Figures 3 and 4), we can begin to interpret the variable As concentrations in the Bangladeshi groundwaters. Several studies, including this one, have observed that the highest As concentrations are located in the shallowest sediments ( $<60 \mathrm{~m})$ [Acharyya et al., 1999; British Geological Survey and Mott MacDonald Ltd., 1999; Chowdhury et al., 1999; Nickson et al., 2000; McArthur et al., 2001]. These sediments began to be deposited about 11,000 years ago and have had the smallest amount of groundwater flushing through them compared to the rest of the stratigraphic column. As Figure 8 demonstrates, there is a general decrease in the $\mathrm{As} / \mathrm{Fe}$ molar ratios with depth, probably resulting from more water flowing through the lower sediments thus removing some of the adsorbed As. Assuming no further addition of arsenic by weathering of mica and using the Laxmipur recharge rate and dissolved As levels, it would take 300-500 years and $\sim 15 \mathrm{~L}$ of As-free groundwater flushing through $1 \mathrm{~L}$ of aquifer to lower the dissolved As concentration below $0.5 \mu \mathrm{mol}$ in the Laxmipur wells. In the deeper samples, there appears to be a limit on dissolved As and a finite supply of As even with high levels of dissolved $\mathrm{Fe}$ released to the groundwater.

[31] When we examined individual sites (e.g., Laxmipur, Faridpur), the positive correlations between arsenic and methane, iron, and ammonia became readily apparent. The samples in Laxmipur and Faridpur (Figure 4) have methane levels greater than $30 \mu \mathrm{mol} / \mathrm{L}$ and a strong correlation between $\mathrm{Fe}$ and $\mathrm{As}\left(\mathrm{r}^{2}=0.8\right)$. The average Laxmipur groundwater $\mathrm{As} / \mathrm{Fe}$ molar ratio is $0.090 \pm 0.030$ or hundred times greater than the adsorbed $\mathrm{As} / \mathrm{Fe}$ molar ratios, which indicates that the As release is not a simple stoichiometric 


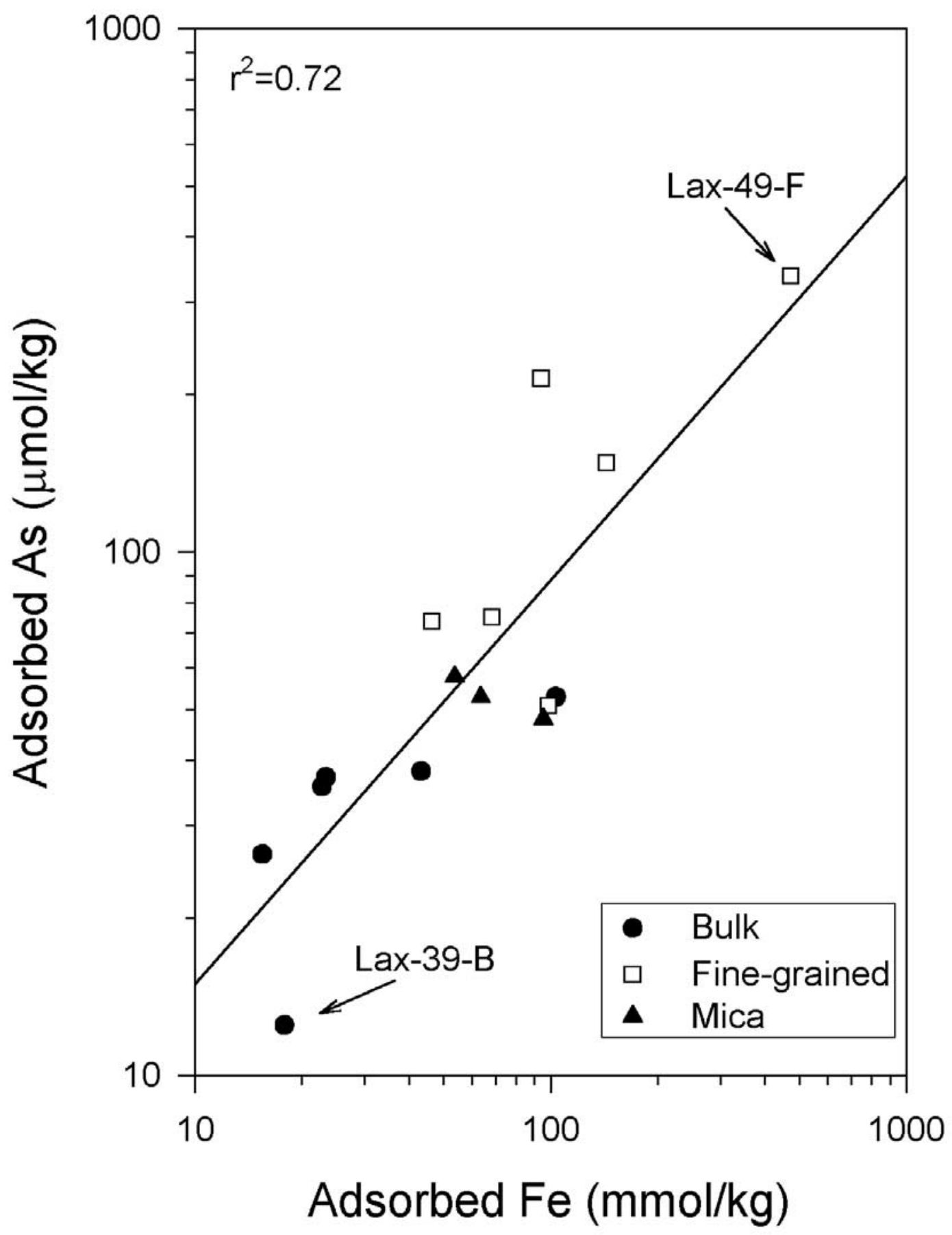

Figure 7. Adsorbed Fe versus adsorbed As in the sediment fractions. There is an overall correlation $\left(\mathrm{r}^{2}=\right.$ 0.72 ) between adsorbed Fe and As indicating that $\mathrm{Fe}$ and As come from a similar source. It also points out the importance of grain size on trace metals because the bulk sediment has the lowest concentrations of As and $\mathrm{Fe}$ while the fine-grained fraction has the highest levels.

FeOOH breakdown. Adsorption of dissolved $\mathrm{Fe}$ and/or the precipitation of siderite may occur. Once siderite $\left(\mathrm{FeCO}_{3}\right)$ solubility is reached in the groundwater, dissolved iron levels should no longer increase because of mineral precipitation. Curiously, the dissolved As/Fe molar ratios in the groundwater are relatively consistent and independent of the arsenic and iron concentrations. Even though arsenic is more soluble in groundwater than iron, the arsenate and arsenite oxy-anions are still subject to adsorption/desorption reactions on mineral surfaces. The modest correlation of total As with the molybdate oxy-anion, $\mathrm{MoO}_{4}^{2-}\left(\mathrm{r}^{2}=0.6\right)$ may reflect the influence of surface adsorption. Other redox 


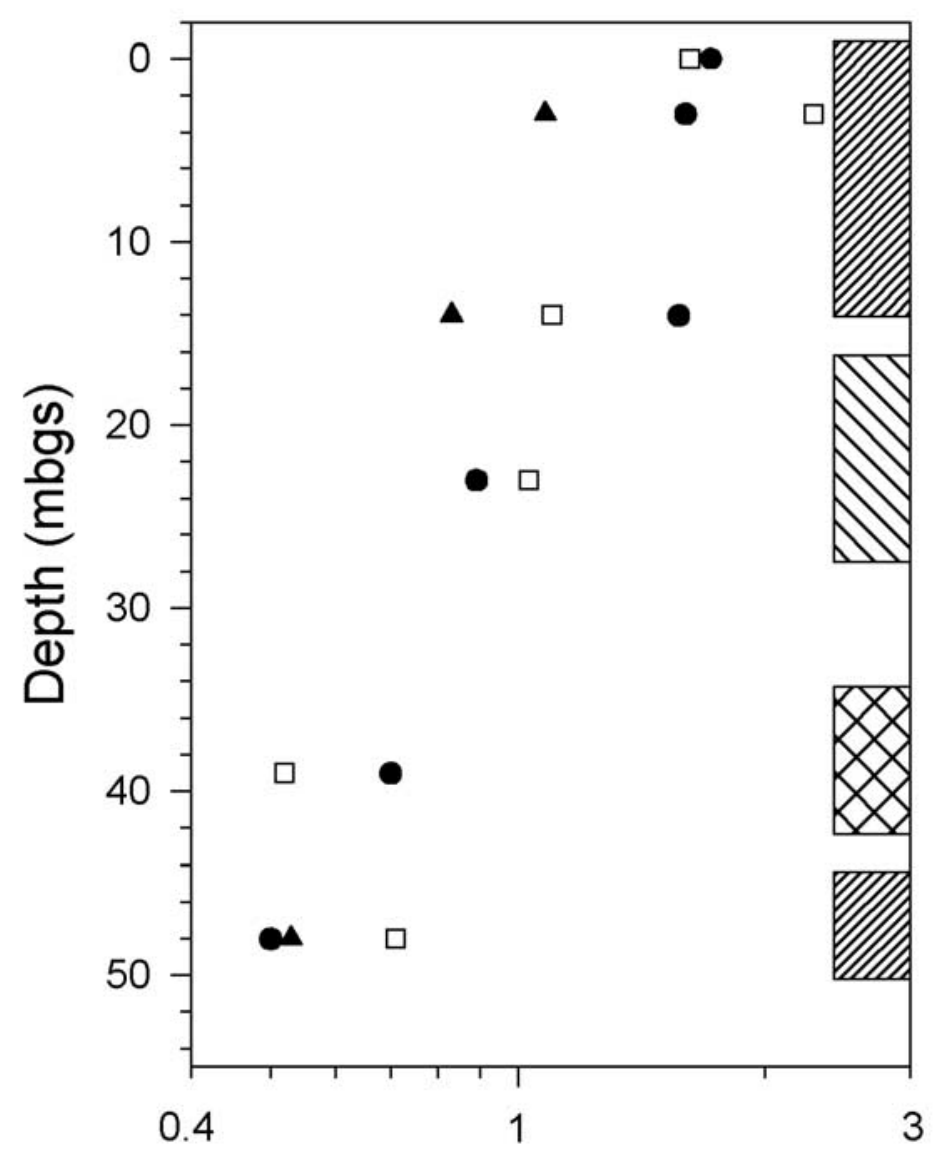

Solid Phase As/Fe (x1000)

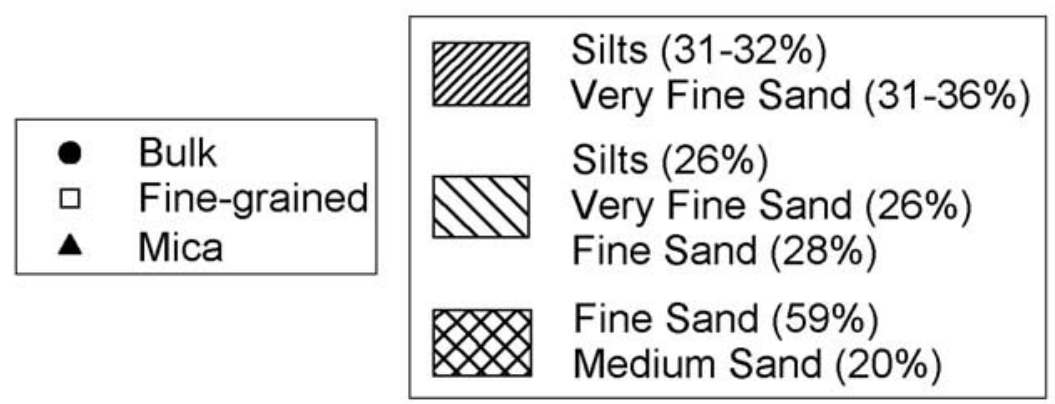

Figure 8. Adsorbed As-Fe molar ratios plotted against depth. There is an overall decrease in the ratios with depth, resulting from more groundwater flushing the lower sediments and removing some of the adsorbed As from the system.

sensitive species, such as methane and ammonia, that are generated by bacterial reduction of organic matter, display strong correlation coefficients with As $\left(\mathrm{r}^{2}=0.9\right)$. Neither methane nor ammonia are adsorbed on mineral surfaces (unlike $\mathrm{MoO}_{4}^{2-}$ ) or released by the breakdown of $\mathrm{FeOOH}$. We agree with the hypothesis put forth by McArthur et al. [2001] who propose that the biogenic decomposition of organic matter is the primary driver behind the dissimilatory reduction of iron and the presence of arsenic, phosphate, methane, and ammonia in the groundwater.

[32] Cummings et al. [1999] have shown that As can be released into solution by bacterially reductive dissolution of iron. Shewanella alga BrY, a dissimilatory iron-reducing bacterium, facilitates As mobilization from crystalline ferric arsenate as well as from sediment sorption sites [Cummings et al., 1999]. Even though Shewanella alga BrY may cause As to be mobilized in both synthetic substrates and natural sediment, the oxidization state of arsenic $[\mathrm{As}(\mathrm{V})]$ remains unaltered. It may be that As(III), the more mobile and toxic arsenic, in groundwater is a twofold process. The ironreducing bacteria introduce arsenic into the solution through the dissolution of $\mathrm{FeOOH}$. If the arsenic is dominantly $\mathrm{As}(\mathrm{V})$, then arsenic reduction happens either directly from arsenic reducing bacteria or indirectly by chemical reduc- 


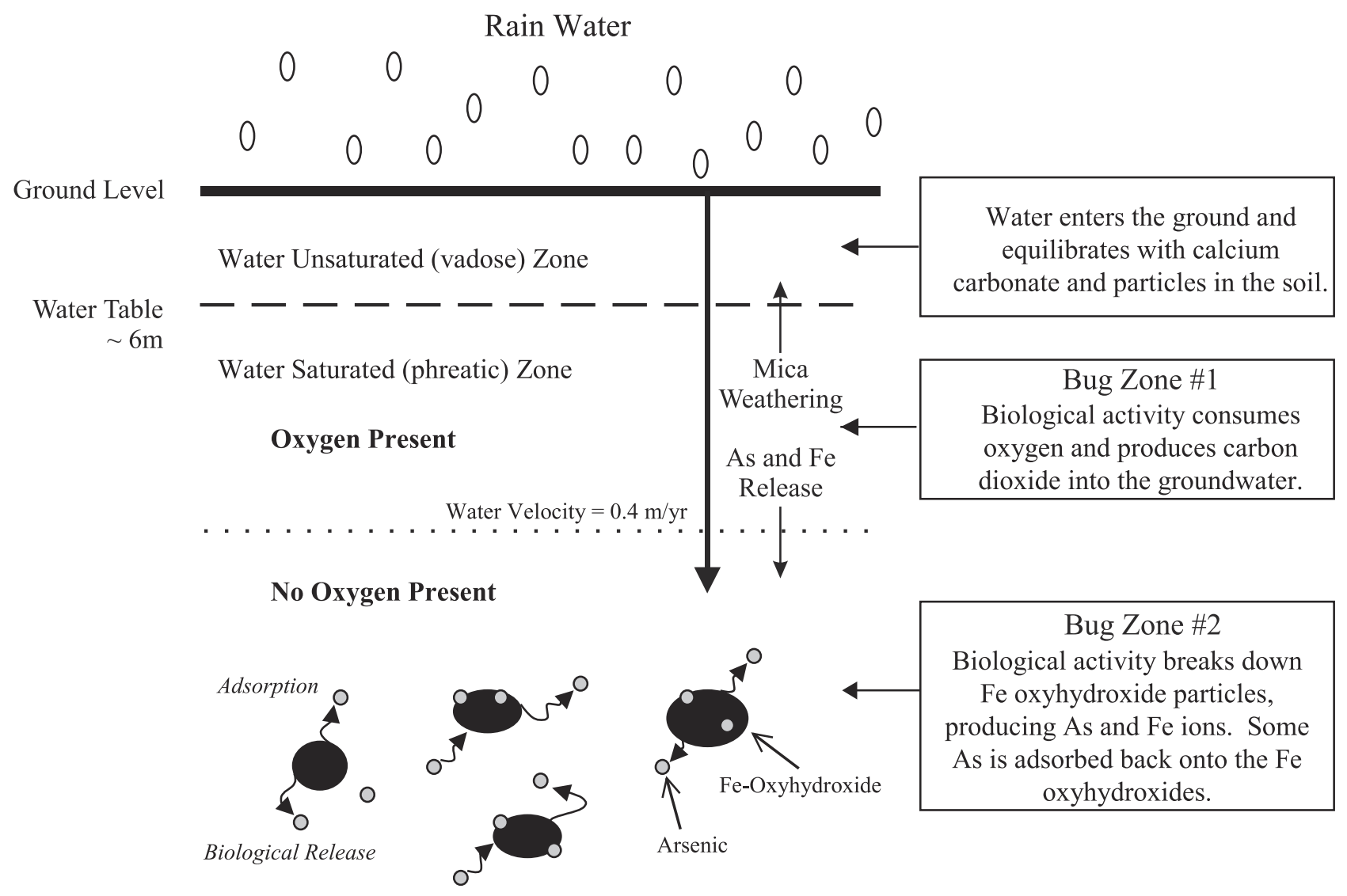

$\sim 150 \mathrm{~m}$

Figure 9. Schematic diagram of the Bengal Basin groundwater system. The rainwater, in equilibrium with atmospheric gas, percolates into the vadose zone where the water dissolves carbonates and other soluble minerals from the soil. The water further flows into the phreatic zone $(\geq 6 \mathrm{~m})$ where it becomes isolated from exchange with the atmosphere. The aerobic organisms consume the oxygen to metabolize organic matter and introduce carbon dioxide into the groundwater. Once all the oxygen is used, anaerobic microbes break down iron oxy-hydroxides for energy which introduces $\mathrm{CO}_{2}, \mathrm{Fe}$, and As into the groundwater. The concentration of dissolved arsenic is controlled by biological activity and adsorption reactions. Not drawn to scale.

tion [Cummings et al., 1999]. Ahmann et al. [1994] reports that a microorganism, MIT-13, can reduce arsenate $[\mathrm{As}(\mathrm{V})]$ to arsenite $[\mathrm{As}(\mathrm{III})]$. Those organisms that are capable of both $\mathrm{Fe}(\mathrm{III})$ and $\mathrm{As}(\mathrm{V})$ reduction, such as Geospirillum barnesii SES-3, would promote rapid As mobilization [Laverman et al., 1995]. These microbes could release As into solution and reduce the available iron oxides to adsorb arsenic, thereby forcing As to stay in solution.

\subsection{Modeling}

[33] We modeled the groundwater system using our dissolved data from the Laxmipur well cluster by constructing a 1-D flow/chemical reactor model to evaluate the rate of iron and arsenic release (Figure 9) [Peters, 2001]. We used simplifying assumptions based on $\mathrm{CaCO}_{3}$ equilibrium for a given $\mathrm{P}_{\mathrm{CO} 2}$ and measured bicarbonate values. The initial condition of $\mathrm{P}_{\mathrm{CO} 2}$, and the rates at which $\mathrm{FeOOH}$ and $\mathrm{O}_{2}$ are consumed are important variables that influence the microbial mediated breakdown of $\mathrm{FeOOH}$, and the subsequent release of arsenic in the groundwater. We used literature values for the constant parameters (equilibrium constants and activity coefficients). The dynamic variables are the rates of $\mathrm{CaCO}_{3}$ dissolution, $\mathrm{FeCO}_{3}$ precipitation, the exponential decay of Fe production $(\lambda)$, consumption of dissolved $\mathrm{O}_{2}$ in the aerobic zone $\left(\mathrm{k}_{\text {bug } 1}\right)$, and biological release of iron via the breakdown of $\mathrm{FeOOH}$ in the anaerobic zone $\left(\mathrm{k}_{\text {bug } 2}\right)$. We ran the model with several combinations and ranges of variables to establish the best fit to the field data.

[34] Rainwater percolates into the vadose zone, and the water equilibrates with the elevated soil $\mathrm{CO}_{2}$ from plant respiration and the $\mathrm{CaCO}_{3}$ in the vadose zone yielding high dissolved $\mathrm{HCO}_{3}$ and $\mathrm{P}_{\mathrm{CO} 2}$ as initial conditions. The water must enter the phreatic zone saturated with $\mathrm{CaCO}_{3}$ and at high $\mathrm{P}_{\mathrm{CO} 2}$ or the model $\left[\mathrm{H}^{+}\right]$and total $\mathrm{CO}_{2}$ at depth will be too low. Once the water further flows into the phreatic zone $(\geq 6 \mathrm{~m})$, it becomes isolated from exchange with the soil gas. Aerobic organisms (bug zone 1) consume the dissolved oxygen $\left(\mathrm{O}_{2}=0.3 \mathrm{mM}\right)$ in the groundwater to metabolize organic matter and release $\mathrm{CO}_{2}$. The addition of carbon dioxide in equilibrium with calcium carbonate increases the concentration of bicarbonate in the groundwater. After aerobic microbes consume all the dissolved oxygen, the 

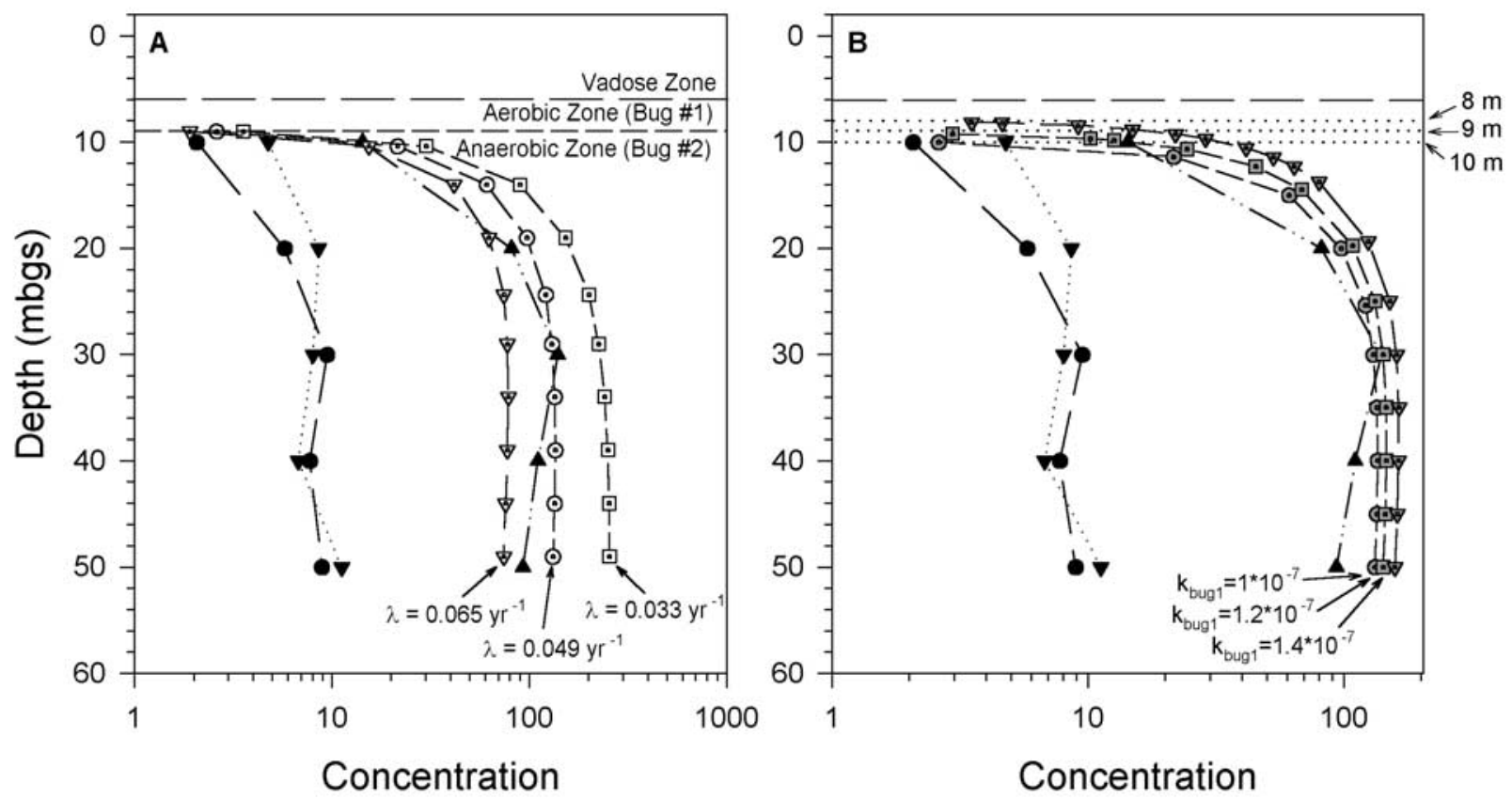

\begin{tabular}{|c|c|c|c|c|c|}
\hline$\Delta$ & Dissolved $\mathrm{Fe}(\mu \mathrm{mol} / \mathrm{L})$ & 回 & Mathcad Fe $(\mu \mathrm{mol} / \mathrm{L}) \lambda=0.033 \mathrm{yr}^{-1}$ & 口 & Mathcad $\mathrm{Fe}(\mu \mathrm{mol} / \mathrm{L}) \mathrm{k}_{\text {bug }}=1.2^{*} 10^{-7}$ \\
\hline • & Dissolved As ( $\mu \mathrm{mol} / \mathrm{L})$ & $\odot$ & Mathcad Fe $(\mu \mathrm{mol} / \mathrm{L}) \lambda=0.049 \mathrm{yr}^{-1}$ & $\odot$ & Mathcad Fe $(\mu \mathrm{mol} / \mathrm{L}) \mathrm{k}_{\text {bug } 1}=1 * 10^{-7}$ \\
\hline $\boldsymbol{\nabla}$ & Dissolved $\mathrm{HCO}_{3}(\mathrm{mmol} / \mathrm{L})$ & $\nabla$ & Mathcad Fe $(\mu \mathrm{mol} / \mathrm{L}) \lambda=0.065 \mathrm{yr}^{-1}$ & $\nabla$ & Mathcad Fe $(\mu \mathrm{mol} / \mathrm{L}) k_{\text {bug } 1}=1.4^{*} 10^{-7}$ \\
\hline
\end{tabular}

Figure 10. Comparison of model results and measured data at the Laxmipur well cluster. (a) The natural iron production slows with depth due to an unknown biological factor $(\lambda)$ such as As poisoning, a limiting reagent that inhibits the microbial breakdown of $\mathrm{FeOOH}$, organic carbon availability, or another unknown factor. The model iron concentration is most similar to the field data when we use a $\lambda$ value of $0.049 \mathrm{yr}^{-1}$. (b) The rate that aerobic microbes consume dissolved $\mathrm{O}_{2}$ affects the depth at which aerobes are replaced by anaerobes. Based on our modeling, the change from aerobic to anaerobic activity is made at $9.0 \pm 0.5 \mathrm{~m}$. The bacterial breakdown of $\mathrm{FeOOH}$ produces $\sim 20 \mu \mathrm{M} / \mathrm{yr}$ of dissolved iron and represents our best model fit based on the data.

anaerobic microbes (bug zone 2) become the dominant carbon dioxide producers by breaking down iron oxyhydroxides to oxidize organic matter $[4 \mathrm{FeOOH}+$ $3 \mathrm{CH}_{2} \mathrm{O}$ (bug 2) $\left.\rightarrow 4 \mathrm{Fe}^{2+}+5 \mathrm{H}_{2} \mathrm{O}+3 \mathrm{CO}_{2}\right]$. The bacterial dissimilatory reduction of $\mathrm{FeOOH}$ releases $\mathrm{CO}_{2}, \mathrm{Fe}$, and any adsorbed trace metals (e.g. As) into the groundwater. Even though methanogens are active in the groundwater and generate both $\mathrm{CO}_{2}$ and $\mathrm{CH}_{4}\left(2 \mathrm{C}_{\text {organic }}+2 \mathrm{H}_{2} \mathrm{O}=\mathrm{CO}_{2}+\right.$ $\mathrm{CH}_{4}$ ), we do not consider them in our model since they do not produce $\mathrm{Fe}$ or As during the decomposition of organic carbon. However, the dissolved $\mathrm{CH}_{4}, \mathrm{NH}_{4}, \mathrm{Fe}$, and $\mathrm{As}$ correlations strongly relate microbial activity and the respiration of organic carbon to the dissimilatory reduction of $\mathrm{FeOOH}$ and the subsequently high concentrations of dissolved As.

[35] The dissolved data and the model results are displayed in Figure 10. The system of equations are written as follows [Peters, 2001]:

$$
\begin{aligned}
& \mathrm{CO}_{2}(\mathrm{~g})+\mathrm{H}_{2} \mathrm{O} \stackrel{\mathrm{K}_{\mathrm{CO}_{2}}}{\longleftrightarrow} \mathrm{H}_{2} \mathrm{CO}_{3} \quad \mathrm{~K}_{\mathrm{CO} 2}=10^{-1.47} \\
& \mathrm{P}_{\mathrm{CO}_{2}} \quad \mathrm{C}_{\mathrm{G}} \\
& \mathrm{H}_{2} \mathrm{CO}_{3} \stackrel{\mathrm{K}_{1}}{\longleftrightarrow} \mathrm{H}^{+}+\mathrm{HCO}_{3}^{-} \quad \mathrm{K}_{1}=10^{-6.35} \\
& \mathrm{C}_{\mathrm{G}} \quad \mathrm{C}_{\mathrm{H}} \quad \mathrm{C}_{\mathrm{B}}
\end{aligned}
$$

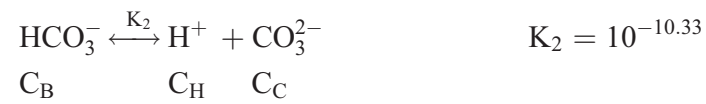

$$
\begin{aligned}
& \begin{aligned}
\mathrm{CaCO}_{3}(\mathrm{~s}) \stackrel{\mathrm{K}_{\mathrm{Cal}}}{\longleftrightarrow} & \mathrm{Ca}^{2+}+\mathrm{CO}_{3}^{2-}
\end{aligned} \quad \mathrm{K}_{\mathrm{Cal}}=10^{-8.48} \\
& \mathrm{Fe}^{2+}+\mathrm{CO}_{3}^{2-} \stackrel{\mathrm{K}_{\mathrm{Fe}}}{\longleftrightarrow} \mathrm{FeCO}_{3}(\mathrm{~s}) \quad \mathrm{K}_{\mathrm{Fe}}=10^{-10.89} \\
& \mathrm{C}_{\mathrm{Fe}} \quad \mathrm{C}_{\mathrm{C}} \\
& \mathrm{CH}_{2} \mathrm{O}+\mathrm{O}_{2} \stackrel{\mathrm{K}_{\text {BUG } 1}}{\longleftrightarrow} \mathrm{CO}_{2}+\mathrm{H}_{2} \mathrm{O} \\
& \text { Bug } 1 \quad \mathrm{C}_{\mathrm{O}} \quad \mathrm{C}_{\mathrm{G}} \\
& 3 \mathrm{CH}_{2} \mathrm{O}+4 \mathrm{FeOOH}(\mathrm{As}) \stackrel{\mathrm{K}_{\mathrm{BUG} 2}}{\longleftrightarrow} 3 \mathrm{CO}_{2}+4 \mathrm{Fe}^{2+}+5 \mathrm{H}_{2} \mathrm{O} \\
& \text { Bug } 2 \quad \mathrm{C}_{\mathrm{FO}} \quad \mathrm{C}_{\mathrm{G}} \quad \mathrm{C}_{\mathrm{F}}
\end{aligned}
$$

We assume that the first equation occurs instantaneously; therefore it has been omitted when creating the mass balances and replaced with $\mathrm{C}_{\mathrm{G}}=\mathrm{P}_{\mathrm{CO} 2} * \mathrm{~K}_{\mathrm{CO} 2}$. The mass balances on each species are as follows [Peters, 2001]: 


$$
\begin{aligned}
& \frac{d C_{G}}{d t}=-K_{1} \cdot k_{1 m} \cdot C_{G}+k_{1 m} \cdot \gamma_{H_{C O}^{-}} \cdot C_{B} \cdot C_{H}+k_{b u g 1}+k_{b u g 2} \\
& \begin{aligned}
\frac{d C_{B}}{d t}= & K_{1} \cdot k_{1 m} \cdot C_{G}-k_{1 m} \cdot \gamma_{H C O_{3}^{-}} \cdot C_{B} \cdot C_{H}-K_{2} \cdot k_{2 m} \cdot \gamma_{H C O_{3}^{-}} \\
& \cdot C_{B}+k_{2 m} \cdot \gamma_{C O_{3}^{2-}} \cdot C_{C} \cdot C_{H}
\end{aligned} \\
& \frac{d C_{H}}{d t}=K_{1} \cdot k_{1 m} \cdot C_{G}-k_{1 m} \cdot \gamma_{H C O_{3}^{-}} \cdot C_{B} \cdot C_{H} \\
& +K_{2} \cdot k_{2 m} \cdot \gamma_{\mathrm{HCO}_{3}^{-}} \cdot C_{B}-k_{2 m} \cdot \gamma_{C_{3}^{2-}} \cdot C_{C} \cdot C_{H} \\
& \frac{d C_{C}}{d t}=K_{2} \cdot k_{2 m} \cdot \gamma_{H_{C O}^{-}} \cdot C_{B}-k_{2 m} \cdot \gamma_{C O_{3}^{2-}} \cdot C_{C} \cdot C_{H} \\
& +k_{\mathrm{Cal}} \cdot\left(\frac{K_{\mathrm{Cal}}}{\gamma_{\mathrm{CO}_{3}^{2-}} \cdot C_{\mathrm{C}}}-\gamma_{\mathrm{Ca}^{2+}} \cdot C_{\mathrm{Ca}}\right) \\
& +k_{\mathrm{Fe}} \cdot\left(\frac{K_{\mathrm{Fe}}}{\gamma_{\mathrm{CO}_{3}^{2-}} \cdot C_{\mathrm{C}}}-\gamma_{\mathrm{Fe}^{2+}} \cdot C_{\mathrm{Fe}}\right) \\
& \frac{d C_{C a}}{d t}=k_{d i s s} \cdot\left(\frac{K_{3}}{\gamma_{C O_{3}^{2-}} \cdot C_{C}}-\gamma_{C a^{2+}} \cdot C_{C a}\right) \\
& \frac{d C_{F e}}{d t}=\frac{4}{3} \cdot\left(k_{\text {bug } 2} \cdot e^{-\lambda \cdot t}\right)+k_{F e} \cdot\left(\frac{K_{F e}}{\gamma_{C O_{3}^{2-}} \cdot C_{C}}-\gamma_{F e^{2+}} \cdot C_{F e}\right) \\
& \frac{d C_{O}}{d t}=-k_{b u g 1}
\end{aligned}
$$

We choose an initial $\mathrm{P}_{\mathrm{CO} 2}$ of $10^{-1.5}$ atm to match our field $\mathrm{pH}$ and bicarbonate values at calcium carbonate saturation, and we use our measured groundwater velocity of $0.4 \mathrm{~m} / \mathrm{yr}$. Bicarbonate and calcium concentrations have the greatest discrepancies between the model results and the measured data since we have not accounted for all the sources of solid-phase carbonates (e.g. dolomite) or the high levels of calcium from seawater flooding. The best fit to the data requires that the natural iron production decreases exponentially $(\lambda)$, caused by either As poisoning, a limiting reagent such as Mo that inhibits the bacterial breakdown of $\mathrm{FeOOH}$, organic carbon availability, or another unknown factor.

[36] The rate that aerobic microbes $\left(\mathrm{k}_{\text {bug } 1}\right)$ consume $\mathrm{O}_{2}$ affects the depth at which aerobes are replaced by anaerobes. Figure 10b shows that the best fit for the change from aerobic

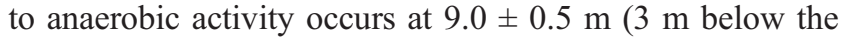
water table). The $\sim 20 \mu \mathrm{M} / \mathrm{yr}$ generation of dissolved iron via bacterial breakdown represents our best model fit based on our measured data. If the average measured dissolved $\mathrm{As} / \mathrm{Fe}$ is $0.09 \pm 0.03$, then the rate at which As is liberated into the groundwater is $1.8 \pm 0.6 \mu \mathrm{M} / \mathrm{yr}$. Based on the rapidity of the microbial mediated breakdown of the $\mathrm{FeOOH}$, its subsequent release of arsenic, the elevated levels of adsorbed As, and the rate of groundwater flow, the high levels of dissolved arsenic in the groundwater will be a long-term problem in the shallow wells of the Bengal Basin.

\subsection{Dual Permeability}

[37] Another important factor to consider is the influential role of sediment permeability in the release and distribution of arsenic to the groundwater. The highest levels of dissolved As are observed in the shallow fine-grained organicrich sediments of Faridpur and Laxmipur. However, many of the wells that supply the villages in the Bengal Basin have mildly anaerobic waters (field Eh of 0 to $+150 \mathrm{mv}$ and arsenate/arsenite ratios of 1) that are not conducive to $\mathrm{CH}_{4}$ and $\mathrm{NH}_{4}$ production but still have elevated As which correlates with methane and ammonia. These water supply wells are screened in high permeability, sandy zones (e.g., BGD 14, 15, 29) in contrast to the low permeable high-As horizons of Faridpur and Laxmipur. We would propose that the levels of As, $\mathrm{CH}_{4}$, and $\mathrm{NH}_{4}$ dissolved in the groundwater are controlled by the relative proportions of low and high permeability sediments. The dissolved $\mathrm{As}, \mathrm{CH}_{4}$, and $\mathrm{NH}_{4}$, are diffusing from clay-rich areas into the sandy units with low levels or no $\mathrm{As}, \mathrm{CH}_{4}$, and $\mathrm{NH}_{4}$. The Fe does not spread into the sandy layers as readily since it re-precipitates either as $\mathrm{FeCO}_{3}$ or $\mathrm{FeOOH}$.

[38] Understanding the spatial distribution of arsenic on the sediments from As-bearing localities will also have a strong bearing on our conceptual model of As release. A preliminary examination of five samples from a single core (3 to $49 \mathrm{~m}$ depth) at Laxmipur reveals an average value of $35 \pm 14 \mu \mathrm{M}$ of adsorbed As on the bulk sediments while the associated waters display an average As concentration of $6.8 \pm 3 \mu \mathrm{M}$. In addition, the sandy modern day sediments, collected near the confluence of the Ganges and Brahmaputra, contain a comparable amount of adsorbed (oxalateextractable) arsenic (average $26.5 \pm 8 \mu \mathrm{M}$ ). Thus, in the case of these bulk sediment samples from Laxmipur drill core and the sediments from the Ganges and Brahmaputra riverbeds, the analyzed bulk sediments do appear capable of supplying all of the dissolved arsenic to the water. It is most likely coming from the finer-grained sediments (e.g. claysized) that contain five times more sorbed As and Fe than the bulk sediments or the mica separates. In the British Geological Survey and Mott MacDonald Ltd. [1999] study, the highest levels of adsorbed As (released by oxalate extraction) also occur in the clay-rich layers as opposed to the more sandy lenses within the Nawabganj core.

[39] The fine-grained As-bearing $\mathrm{FeOOH}$ colloids are typically deposited in low-energy environments at the seawater/freshwater interface (i.e. an estuary or tidal channel). The flocculation hypothesis also accounts for the geographical concentration of As-bearing wells that exist in a broad band trending WNW-ESE, subparallel to the course of the Ganges (Figure 1) that presumably coincides with the river-seawater paleo-transition zone. Another theory compatible with our results is that the distribution of peat and organic matter in the subsurface controls the As release and distribution in the groundwater [McArthur et al., 2001]. Peat and organic matter are found at depth in the Bengal Basin [Umitsu, 1993; Goodbred and Kuehl, 2000] and forms in the low energy environments as organic matter collects in estuaries or wetlands rather than active river channels. Ultimately, they form low permeability zones within the subsurface and a source of energy for microbes.

[40] An additional reason for the present distribution of As-bearing groundwater is the Recent age of the shallow sediments. Sediments older than 10,000 years old were deposited when sea level was lower and large quantities of fresh water flowed through the sediments removing nearly all adsorbed As. If the average present day recharge rate of $60 \pm 20 \mathrm{~cm} / \mathrm{yr}$ existed for the past $100 \mathrm{kyr}$, the sediments from 50 to $250 \mathrm{~m}$ depth have been flushed by more than 100 
pore volumes of water. Conversely, most of the shallow sediments $(<60 \mathrm{~m})$, deposited since the last significant drop in sea level, have seen fewer than 20 pore volumes. The volume of water flushing through fine-grained, low permeability sediments would be considerably less.

[41] The ultimate source of arsenic in the groundwater may be from the weathering of micas and the result of a multistage weathering process. Mica, with its high intrinsic arsenic, weathers into clay and releases arsenic and other trace elements into the water. The As is scavenged by $\mathrm{FeOOH}$ and flocculates as fine-grained particles in estuaries and other low energy environments. The XAFS (X-ray absorption fine structure) data of Foster et al. [2000] show that the more toxic As(III) species dominate the upper gray to black micaceous fine-grained sediment $(6-25 \mathrm{~m})$ in Ramrail, Brahmanbaria (near Dhaka) while the less mobile $\mathrm{As}(\mathrm{V})$ is found sorbed onto $\mathrm{FeOOH}$ in the oxidized quartz and weathered mica sediment (26-48 m depth). Through sediment desorption reactions, bacterial dissolution of $\mathrm{FeOOH}$, and the microbial mediated transformation of $\mathrm{As}(\mathrm{V})$ to $\mathrm{As}(\mathrm{III}), \mathrm{As}(\mathrm{III})$ is being introduced into the groundwater. However, we are unable to distinguish between As coming from the As-FeOOH colloids that were flocculated at the freshwater/saltwater interface and the arsenic adsorbed on $\mathrm{FeOOH}$ after the As was weathered from the high-arsenic mica in the aquifer.

[42] We expect the arsenic concentrations to remain above the WHO standard in post-glacial sediments for a long period of time in As-bearing localities because of the enhanced microbial activity in the groundwater, the distribution of organic matter and peats, dual permeability sediments in the subsurface, the diffusion of As into the sandy layers, and the young age of the shallow sediments.

\section{Conclusions}

[43] Dissolved arsenic in the groundwater of the Bengal Basin represents a considerable health risk to a population that relies on tube wells for their water supply. The majority of high As groundwater wells in the Bengal Basin are moderately reducing, have high dissolved $\mathrm{Fe}, \mathrm{CH}_{4}$, and $\mathrm{NH}_{4}$, and contain no dissolved $\mathrm{O}_{2}$ or $\mathrm{SO}_{4}$. The As-laden wells of Laxmipur and Faridpur have groundwater residence times of greater than $60 \mathrm{yrs}$, which eliminates the causal link between the recent application of phosphatic fertilizers and excessive extraction of groundwater for irrigation in recent years and As release into the groundwater. We believe that the arsenic is being liberated from the sediment into the moderately reducing groundwater by the microbial mediated reductive dissolution of iron oxyhydroxides. The strong correlations between high levels of dissolved arsenic with iron, methane, and ammonia support the bacterial breakdown of $\mathrm{FeOOH}$.

[44] Physical adsorption and desorption reactions have significant effects on the concentrations of dissolved trace elements in groundwater. The analyzed bulk sediments do appear capable of supplying all of the dissolved arsenic, mostly through desorption and $\mathrm{FeOOH}$ dissolution, to the groundwater. The fine-grained particles in Laxmipur core have elevated levels of extractable arsenic compared to the bulk sediments and mica separates, implying that the surface area has a significant control on groundwater arsenic levels. The adsorbed As-Fe molar ratios decrease with depth throughout the stratigraphic column suggesting that some of the arsenic has been flushed from the system since the lower sediments have had more water flowing through them than the upper layers. The data from the digestions of the mica separates indicate that the weathering of mica at least contributes and may be the ultimate source of arsenic. Arsenic released from mica is subsequently adsorbed onto iron oxy-hydroxides and now is being re-introduced into the groundwater through the microbial dissolution of $\mathrm{FeOOH}$. However, we are unable to differentiate between the arsenic coming from As-bearing iron oxy-hydroxides being flocculated and the arsenic adsorbed on $\mathrm{FeOOH}$ after the As was weathered from the aquifer mica. Our model illustrates that the bacterial breakdown of iron oxy-hydroxides can release As into the groundwater at a rate of $1.8 \pm 0.6 \mu \mathrm{M} / \mathrm{yr}$.

[45] The hydraulic conductivity of the sediments also has a considerable impact on groundwater chemistry. Groundwater residence times and subsurface stratigraphy suggest that the presence of the As in water supply wells is the result of diffusion out of the organic-rich clay into the more permeable sandy zones. The data also suggests that the As is mainly released from Holocene sediments since large quantities of water have not flushed the dissolved arsenic from the aquifers.

[46] The dissolved arsenic in the groundwater will remain a long-term problem for the people of Bengal Basin because of microbial dissolution of iron oxy-hydroxides, the subsurface distribution of organic matter and peats, dual sediment permeability, the diffusion limited release of As into the sandy layers, and the young age of the shallow sediments.

[47] Acknowledgments. We would like to thank the International Atomic Energy Agency (IAEA), Vienna, Austria, for sponsoring the field excursions in the Bengal Basin, and the Atomic Energy Agency and the Water Development Board of Bangladesh (BWDB) and the Central Groundwater Board of West Bengal, India for field support. In particular, we are appreciative of Reazuddin Ahmed and Mizanur Rahman of the BWDB, and K. M. Kulkarni, now of the IAEA in Vienna, for their assistance and guidance in the field procurement of the groundwater samples in Bangladesh and West Bengal State, India, respectively. We thank Billy Moore from the University of South Carolina for the GangesBrahmaputra River sediment samples, and Andrew G. Hunt, Magdalyn J. Renz, and Gregory L. Wortman for lab assistance. We also would like to express our thanks to the Associate Editor and two anonymous reviewers for their constructive comments and suggestions. This research was partially funded by NSF 9730743.

\section{References}

Acharyya, S. K., P. Chakraborty, S. Lahiri, B. C. Raymahashay, S. Guha, and A. Bhowmilk, Arensic poisoning in the Ganges Delta, Nature, 401, $545,1999$.

Acharyya, S. K., S. Lahiri, B. C. Raymahashay, and A. Bhowmilk, Arsenic toxicity of groundwater in parts of the Bengal Basin in India and Bangladesh: The role of Quaternary stratigraphy and Holocene sea-level fluctuation, Environ. Geol., 39, 1127-1137, 2000.

Ahmann, D., A. L. Roberts, L. R. Krumholz, and F. M. M. Morel, Microbe grows by reducing arsenic, Nature, 371, 750, 1994.

Allison, M. A., Historical changes in the Ganges-Brahmaputra Delta front, J. Coastal Res., 14, 1269-1275, 1998.

Biswas, B. K., R. K. Dhar, G. Samanta, B. K. Mandal, D. Chakraborti, I. Faruk, K. S. Islam, M. M. Chowdhury, A. Islam, and S. Roy, Detailed study report of Samta, one of the arsenic-affected villages of Jessore District, Bangladesh, Curr. Sci., 74, 134-145, 1998.

British Geological Survey and Mott MacDonald Ltd., Main report: Groundwater studies for arsenic contamination in Bangladesh, Keyworth, UK, 1999. 
Chowdhury, T. R., et al., Arsenic poisoning in the Ganges Delta, Nature, 401, 545-546, 1999.

Clarke, W. B., W. J. Jenkins, and Z. Top, Determination of tritium by mass spectrometric measurement of ${ }^{3} \mathrm{He}$, Int. J. Appl. Radiat. Isot., 27, $515-$ $522,1976$.

Coleman, J. M., Brahmaputra River: Channel processes and sedimentation, Sediment. Geol., 3, 129-239, 1969.

Cummings, D. E., F. Caccavo Jr., S. Fendorf, and R. F. Rosenzweig, Arsenic mobilization by the dissimilatory Fe(III)-reducing bacterium Shewanella alga BrY, Environ. Sci. Technol., 33, 723-729, 1999.

Das, D., A. Chatterjee, B. K. Mandal, G. Samanta, D. Chakraborti, and B. Chanda, Arsenic in ground water in six districts of West Bengal, India; the biggest arsenic calamity in the world; part 2, Arsenic concentration in drinking water, hair, nails, urine, skin-scale and liver tissue (biopsy) of the affected people, in Speciation of Elements: Trace Elements in Human Health, edited by Y. Thomassen and E. Nieboer, pp. 917-924, Chem. Soc., Cambridge, England, 1995.

Das, D., G. Samanta, B. K. Mandal, T. R. Chowdhury, C. R. Chanda, P. P. Chowdhury, G. K. Basu, and K. Chakraborti, Arsenic in groundwater in six districts of West Bengal, India, Environ. Geochem. Health, 18, 5-15, 1996.

Dhar, R. K., et al., Groundwater arsenic calamity in Bangladesh, Curr. Sci., 73, 48-59, 1997.

Fehn, U., G. Synder, and P. K. Egeberg, Dating of pore waters with ${ }^{129} \mathrm{I}$; relevance for the origin of marine gas hydrates, Science, 289, 2332 2335, 2000.

Food and Agricultural Organization (FAO), Soil survey project, Bangladesh, AGL:SF/PAK 6, Tech. Rep. 3, Rome, 1971.

Foster, A. L., G. N. Breit, A. H. Welch, J. W. Whitney, J. C. Yount, M. S Islam, M. M. Alam, M. K. Islam, and M. N. Islam, In-situ identification of arsenic species in soil and aquifer sediment from Ramrail, Brahmanbaria, Bangladesh, Eos Trans. AGU, 81(48), Fall Meet. Suppl., abstract H21D-01, 2000.

Goodbred, S. L., and S. A. Kuehl, The significance of large sediment supply, active tectonism, and eustasy on margin sequence development: Late Quaternary stratigraphy and evolution of the Ganges-Brahmaputra Delta, Sediment. Geol., 133, 227-248, 2000.

Greenberg, A. E., L. S. Clesceri, and A. D. Eaton, Standard Methods for the Examination of Water and Wastewater, 18th ed., Am. Public Health Assoc., Washington, D.C., 1992.

Holeman, J. N., The sediment yield of major rivers in the world, Water Resour. Res., 4, 737-747, 1968.

Karim, M. M., Arsenic in groundwater and health problems in Bangladesh, Water Res., 34, 304-310, 2000.

Laverman, A. M., J. S. Blum, J. K. Schaefer, E. J. P. Phillips, D. R. Lovley, and R. S. Oremland, Growth of strain SES-3 with arsenate and other diverse electron acceptors, Appl. Environ. Microbiol., 61, 3556-3561, 1995.

Li, X., B. J. Coles, M. H. Ramsey, and I. Thornton, Sequential extraction of soils for multielement analysis by ICP-AES, Chem. Geol., 124, 109$123,1995$.

Lindsay, J. F., D. W. Holliday, and A. G. Hulbert, Sequence stratigraphy and the evolution of the Ganges-Brahmaputra Delta complex, $A A P G$ Bull., 75, 1233-1254, 1991.

Long, S. E., and T. D. Martin, Method 200.8, Determination of trace elements in waters and wastes by inductively coupled plasma-mass spectrometry, in Methods for the Determination of Metals in Environmental Samples, pp. 83-122, U.S. Environ. Prot. Agency, Washington, D.C., 1991.

Mallick, S., and N. R. Rajagopal, Groundwater development in the arsenic affected alluvial belt of West Bengal-Some questions, Curr. Sci., 70 , 956-958, 1996

Mandal, B. K., et al., Arsenic in groundwater in seven districts of West Bengal, India-The biggest arsenic calamity in the world, Curr. Sci., 70, 976-986, 1996
Mandal, B. K., G. T. R. Chowdhury, G. Samanta, D. Mukherjee, C. R. Chanda, K. C. Saha, and D. Chakraborti, Impact of safe water for drinking on five families for two years in West Bengal, India, Sci. Total Environ, 218, 185-201, 1998.

McArthur, J. M., P. Ravenscroft, S. Safiullah, and M. F. Thirlwall, Arsenic in groundwater: Testing pollution mechanisms for sedimentary aquifers in Bangladesh, Water Resour. Res., 37, 109-117, 2001.

McKeague, J. A., Manual on soil sampling and methods of analysis, 2nd ed., Can. Soc. of Soil Sci., Ottawa, Ontario, 1978.

Michels, K. H., H. R. Kudrass, C. Hubscher, A. Suckow, and M. Wiedicke, The submarine delta of the Ganges-Brahmaputra: Cyclone-dominated sedimentation patterns, Mar. Geol., 149, 133-154, 1998.

Milliman, J. D., and R. H. Meade, World-wide delivery of river sediment to the oceans, J. Geol., 91, 1-21, 1983.

Moi, W. M., and C. M. Wai, Mobilization of arsenic in contaminated river sediment, in Arsenic in the Environment, part I, Cycling and Characterization, edited by J. Nriagu, pp. 99-118, John Wiley, New York, 1994.

Nickson, R., J. McArthur, W. Burgess, K. M. Ahmed, P. Ravenscroft, and M. Rahman, Arsenic poisoning of Bangladesh groundwater, Nature, 395 , 338, 1998.

Nickson, R. T., J. M. McArthur, P. Ravenscroft, W. G. Burgess, and K. M. Ahmed, Mechanism of arsenic release to groundwater, Bangladesh and West Bengal, Appl. Geochem., 15, 403-413, 2000.

Peters, S. L., Modeling the mechanism for arsenic release in the groundwater of Bangladesh, M.Sc., Univ. of Rochester, Rochester, New York, 2001

Poreda, R. J., and K. A. Farley, Rare gases in Samoan xenoliths, Earth Planet. Sci. Lett., 113, 129-144, 1992.

Poreda, R. J., T. E. Cerling, and D. K. Solomon, Tritium and helium isotopes as hydrologic tracers in a shallow unconfined aquifer, J. Hydrol., 103, 1-9, 1988.

Sarin, M. M., S. Krishnaswami, K. Dilli, B. L. K. Somayajulu, and W. S. Moore, Major ion chemistry of the Ganges-Brahmaputra river system: Weathering processes and fluxes to the Bay of Bengal, Geochim. Cosmochim. Acta, 53, 997-1009, 1989.

Smith, A. H., E. O. Lingas, and M. Rahman, Contamination of drinking water by arsenic in Bangladesh: A public health emergency, Bull. World Health Org., 78, 1093-1103, 2000.

Solomon, D. K., R. J. Poreda, S. L. Schiff, and J. A. Cherry, Tritium and helium 3 as groundwater age tracers in the Borden aquifer, Water Resour. Res., 28, 741-755, 1992.

Solomon, D. K., S. L. Schiff, R. J. Poreda, and W. B. Clarke, A validation of the ${ }^{3} \mathrm{H} /{ }^{3} \mathrm{He}$ method for determining groundwater recharge, Water Resour. Res., 29, 2951-2962, 1993.

Subramanian, V., Chemical and suspended sediment characteristics of rivers of India, J. Hydrol., 44, 37-55, 1979.

To, T. B., D. K. Nordstrom, K. M. Cunningham, J. W. Ball, and R. B McCleskey, New method for the direct determination of dissolved Fe(III) concentration in acid mine waters, Environ. Sci. Technol., 33, 807-813, 1999

Uddin, A., and N. Lundberg, Cenozoic history of the Himalayan-Bengal system: Sand composition in the Bengal Basin, Banglasdesh, Geol. Soc. Am. Bull., 110, 497-511, 1998.

Umitsu, M., Late Quaternary sedimentary environments and landforms in the Ganges Delta, Sediment. Geol., 83, 177-186, 1993.

P. K. Aggarwal, International Atomic Energy Agency, A-1400, Vienna, Austria.

A. R. Basu, S. L. Peters, and R. J. Poreda, Department of Earth and Environmental Sciences, University of Rochester, Rochester, NY 14627 , USA. (carolyn@earth.Rochester.edu)

C. B. Dowling, Byrd Polar Research Center, Ohio State University, 108 Scott Hall, 1090 Carmack Road, Columbus, OH 43210-1002, USA. (dowling.37@osu.edu) 